\title{
ICAMs Redistributed by Chemokines to Cellular Uropods as a Mechanism for Recruitment of T Lymphocytes
}

\author{
Miguel Angel del Pozo,* Carlos Cabañas, ${ }^{\star}$ María C. Montoya,* Ann Ager, ${ }^{\S}$ Paloma Sánchez-Mateos, ${ }^{\|}$ \\ and Francisco Sánchez-Madrid* \\ *Servicio de Inmunología, Hospital de la Princesa, Universidad Autónoma de Madrid, 28006-Madrid, Spain; ${ }^{\star}$ Departamento de \\ Bioquímica y Biología Molecular, Facultad de Medicina, Universidad Complutense de Madrid, 28040-Madrid, Spain; ${ }^{\circledR}$ National \\ Institute for Medical Research, Division of Cellular Immunology, Medical Research Council, London NW7 1AA, United \\ Kingdom; "Servicio de Inmunología, Hospital General Universitario Gregorio Marañón, 28007-Madrid, Spain
}

\begin{abstract}
The recruitment of leukocytes from the bloodstream is a key step in the inflammatory reaction, and chemokines are among the main regulators of this process. During lymphocyte-endothelial interaction, chemokines induce the polarization of T lymphocytes, with the formation of a cytoplasmic projection (uropod) and redistribution of several adhesion molecules (ICAM-1,-3, CD43, CD44) to this structure. Although it has been reported that these cytokines regulate the adhesive state of integrins in leukocytes, their precise mechanisms of chemoattraction remain to be elucidated. We have herein studied the functional role of the lymphocyte uropod. Confocal microscopy studies clearly showed that cell uropods project away from the cell bodies of adhered lymphocytes and that polarized $\mathrm{T}$ cells contact other T cells through the uropod structure. Time-lapse videomicroscopy studies revealed that uropod-bearing T cells were able, through this cellular projection, to contact, capture, and transport additional bystander T cells. Quantitative analysis revealed that the induction of uropods results in a 5-10-fold increase in cell recruitment. Uropod-mediated cell recruitment
\end{abstract}

seems to have physiological relevance, since it was promoted by both $\mathrm{CD} 45 \mathrm{R}^{+}$peripheral blood memory $\mathrm{T}$ cells as well as by in vivo activated lymphocytes. Additional studies showed that the cell recruitment mediated by uropods was abrogated with antibodies to ICAM-1, -3, and LFA-1, whereas mAb to CD43, CD44, CD45, and L-selectin did not have a significant effect, thus indicating that the interaction of LFA-1 with ICAM-1 and -3 appears to be responsible for this process. To determine whether the increment in cell recruitment mediated by uropod may affect the transendothelial migration of T cells, we carried out chemotaxis assays through confluent monolayers of endothelial cells specialized in lymphocyte extravasation. An enhancement of T cell migration was observed under conditions of uropod formation, and this increase was prevented by incubation with either blocking antiICAM-3 mAbs or drugs that impair uropod formation. These data indicate that the cell interactions mediated by cell uropods represent a cooperative mechanism in lymphocyte recruitment, which may act as an amplification system in the inflammatory response.
$\mathrm{T}$ He leukocyte adhesion to endothelium, with subsequent migration through the vascular wall towards inflammatory foci, is a multistep process finely regulated by several proinflammatory factors (Springer, 1995). During this process, circulating leukocytes roll along the endothelium interacting with immobilized cytokines that promote the firm adhesion and subsequent arrest of leukocytes on the vessel wall. Leukocytes then migrate following a chemoattractant gradient and using integrins as migration supporters, crossing the endothelial barrier and the underlying extracellular matrix $(\mathrm{ECM})^{1}$ towards the inflammatory foci. Increasing evidence supports that chemoattractants can regulate the adhesive state of integrins in leukocytes (Springer, 1995), but the mechanism(s) by which these factors guide $\mathrm{T}$ lymphocyte emigration remain(s) unclear.

Several members of the chemokine family have recently been identified as chemoattractants for $\mathrm{T}$ lymphocytes (Schall et al., 1990, 1993; Taub et al., 1993a,b, 1995; Tanaka et al., 1993a,b; Carr et al., 1994; Schall and Bacon,
Please address all correspondence to Francisco Sánchez-Madrid, Servicio de Inmunología, Hospital de la Princesa, Universidad Autónoma de Madrid, Diego de León, 62, 28006-Madrid, Spain. Tel.: 34-1-402-3347; Fax: 34-1-309-2496; E-mail: fsmadrid/princesa@hup.es
1. Abbreviations used in this paper: EC, endothelial cells; ECM, extracellular matrix; HEC, high endothelial cells; PBL, peripheral blood lymphocytes; SF, synovial fluid; TIL, tumor infiltrating lymphocytes. 
1994). These cytokines are a wide family of 70-80-aa (8-10 $\mathrm{kD})$ polypeptides that have been grouped into two subfamilies, the $\alpha$ - or "C-X-C" chemokines, including IL-8/ NAP-1, IP-10, and MGSA/gro, and the $\beta$ - or "C-C" chemokines, such as RANTES, MCP-1, $-2,-3$, and MIP-1 $\alpha$ and $\beta$. Members of both subfamilies, together with lymphotactin, are able to attract different subsets of T lymphocytes (Baggiolini et al., 1994; Schall and Bacon, 1994). It has been proposed that chemokines may direct $\mathrm{T}$ cell migration by activating lymphocyte integrins; in this regard, it has been described that several chemokines increase $\mathrm{T}$ cell binding to endothelial cells (EC); (Tanaka et al., 1993a,b; Taub et al., 1993a,b; Gilat et al., 1994). Moreover, it has been shown that MCP-1 and other C-C chemokines regulate $\beta 1$ integrin-dependent adhesion to ECM components (Carr et al., 1996; Weber et al., 1996). Nevertheless, it seems evident that additional mechanisms must be involved in the emigration of lymphocytes guided by chemokines.

We have previously described the ability of certain $\alpha$ and $\beta$ chemokines to induce a dramatic change in $\mathrm{T}$ cell shape. Chemokines induce the formation of a cytoplasmic projection or uropod on lymphocytes adhered to either EC, endothelial adhesion molecules, or ECM proteins, where several key adhesion molecules are redistributed (del Pozo et al., 1995; Nieto et al., 1996). Interestingly, the engagement of some of these molecules with specific mAbs induced a similar effect (Campanero et al., 1994; Sánchez-Mateos et al., 1995), and therefore these mAbs can be used as powerful tools to mimic the effect caused by chemokines on uropod formation. In this report we demonstrate by confocal microscopy, time-lapse videomicroscopy, and migration assays that lymphocyte adhesion receptor polarization induced by chemokines can significantly contribute to lymphocyte recruitment. These findings further support that uropod-bearing leukocytes may have a key role in inflammatory phenomena.

\section{Materials and Methods}

\section{Cytokines and Reagents}

Recombinant human (rh) RANTES (sp. act. $2-5 \times 10^{3} \mathrm{U} / \mathrm{mg}$, purity $>97 \%$, endotoxin level $<0.1 \mathrm{ng} / \mu \mathrm{g}$ cytokine) and rhMIP-1 $\beta$ (sp. act. 1.6$2.5 \times 10^{4} \mathrm{U} / \mathrm{mg}$, purity $>97 \%$, endotoxin level $<0.1 \mathrm{ng} / \mu \mathrm{g}$ cytokine) were purchased from R\&D Systems (Minneapolis, MN). rhIL-8 (purity $>98 \%$, endotoxin level $<0.1 \mathrm{ng} / \mu \mathrm{g}$ cytokine), rhMCP-1 (purity $>99 \%$ ), and rhMIP- $1 \alpha$ (purity $>99 \%$, endotoxin level $<0.1 \mathrm{ng} / \mu \mathrm{g}$ cytokine) were obtained from PeproTech EC Ltd. (London, UK). Butanedione monoxime, colchicine, and PMA were purchased from Sigma Chemical Co. (St. Louis, MO).

\section{$m A b s$}

The anti-ICAM-3 HP2/19, TP1/24, TP1/25, 140.11, ICR2.1, anti-ICAM-1 Hu5/3, anti-CD18 Lia3/2, anti-CD11a YTH81.5, anti-CD43 TP1/36, antiCD44 HP2/9, anti-CD45 D3/9, anti-CD45RA RP1/11, anti-CD45RO UCHL.1, and anti-L-selectin (CD62L) LAM1/3 mAb used have been described (Spertini et al., 1991; Campanero et al., 1993; Arroyo et al., 1994; del Pozo et al., 1995; Juan et al., 1994; Landis et al., 1994; Luscinskas et al., 1994; Sadhu et al., 1994). P3X63 myeloma protein $\left(\operatorname{IgG}_{1}, \kappa\right)$ was used as negative control.

\section{Protein Substrata}

Recombinant chimeric ICAM-1-Fc and VCAM-1-4D-Fc, consisting of the a
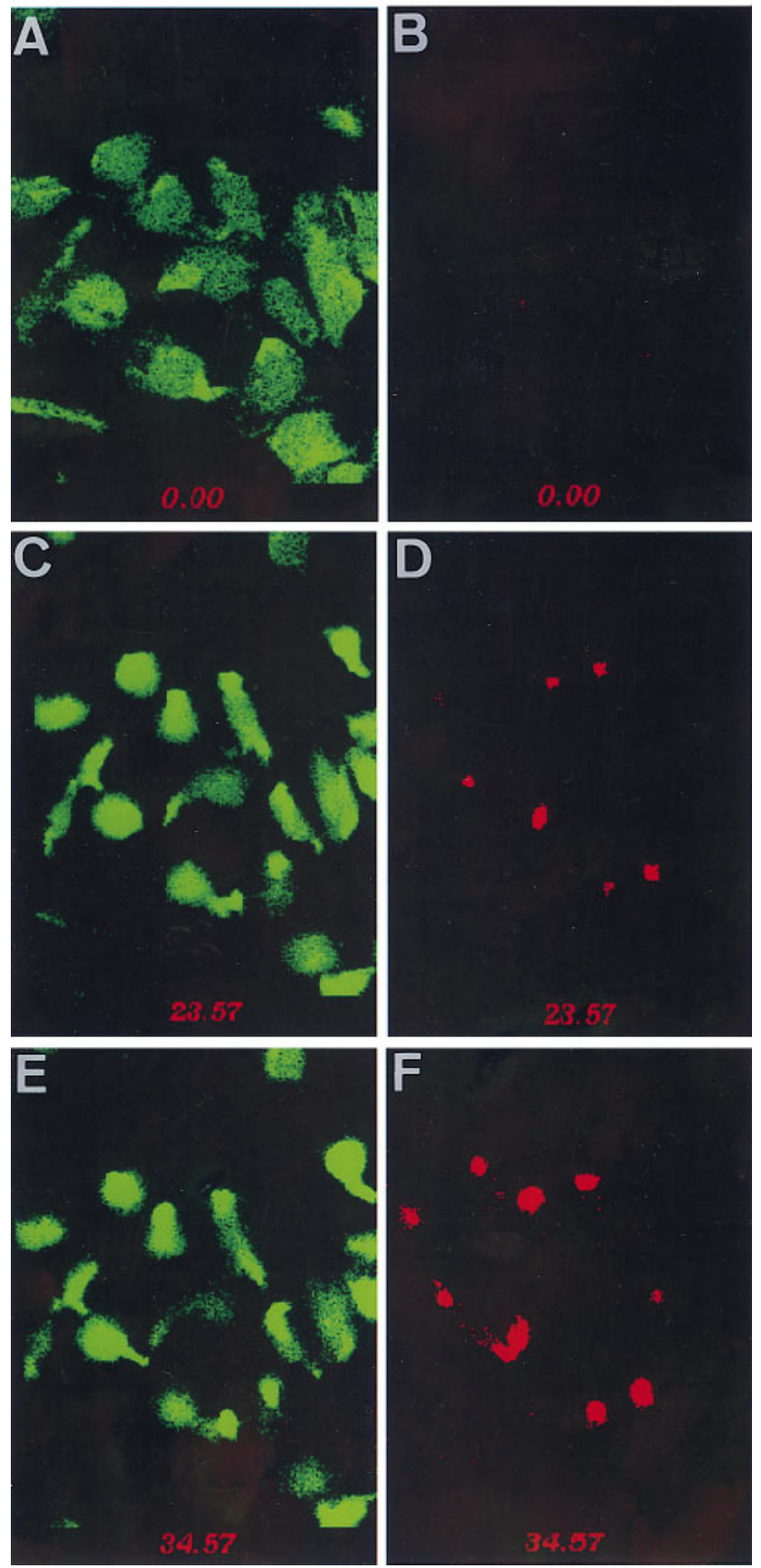

total extracellular domains fused to $\mathrm{IgG}_{1} \mathrm{Fc}$ fragment, were obtained as described (del Pozo et al., 1995). Briefly, COS-7 cells were transiently transfected with pICAM-1-Fc and pVCAM-1-4D-Fc (ICAM-1 and VCAM-1-4D cDNAs cloned in pCD8IgG1). After $4 \mathrm{~d}$, culture supernatants were precipitated with ammonium sulphate, and thereafter, chimeric proteins were isolated by using protein A coupled to Sepharose (Pharmacia Fine Chemicals, Uppsala, Sweden). Fibronectin was purchased from Sigma Chemical Co. BSA was purchased from Boehringer Mannheim GmbH (Mannheim, Germany).

\section{Cells and Cell Lines}

Resting peripheral blood lymphocytes (PBL) were isolated from fresh human blood by Ficoll-Hypaque density gradient centrifugation (Pharmacia Fine Chemicals), followed by two steps of adherence incubation on plastic flasks (Costar Corp., Cambridge, MA) at $37^{\circ} \mathrm{C}$ for $1 \mathrm{~h} . \mathrm{CD}^{2} 5 \mathrm{RA}^{+}$and 
b

\section{UNSTIMULATED}
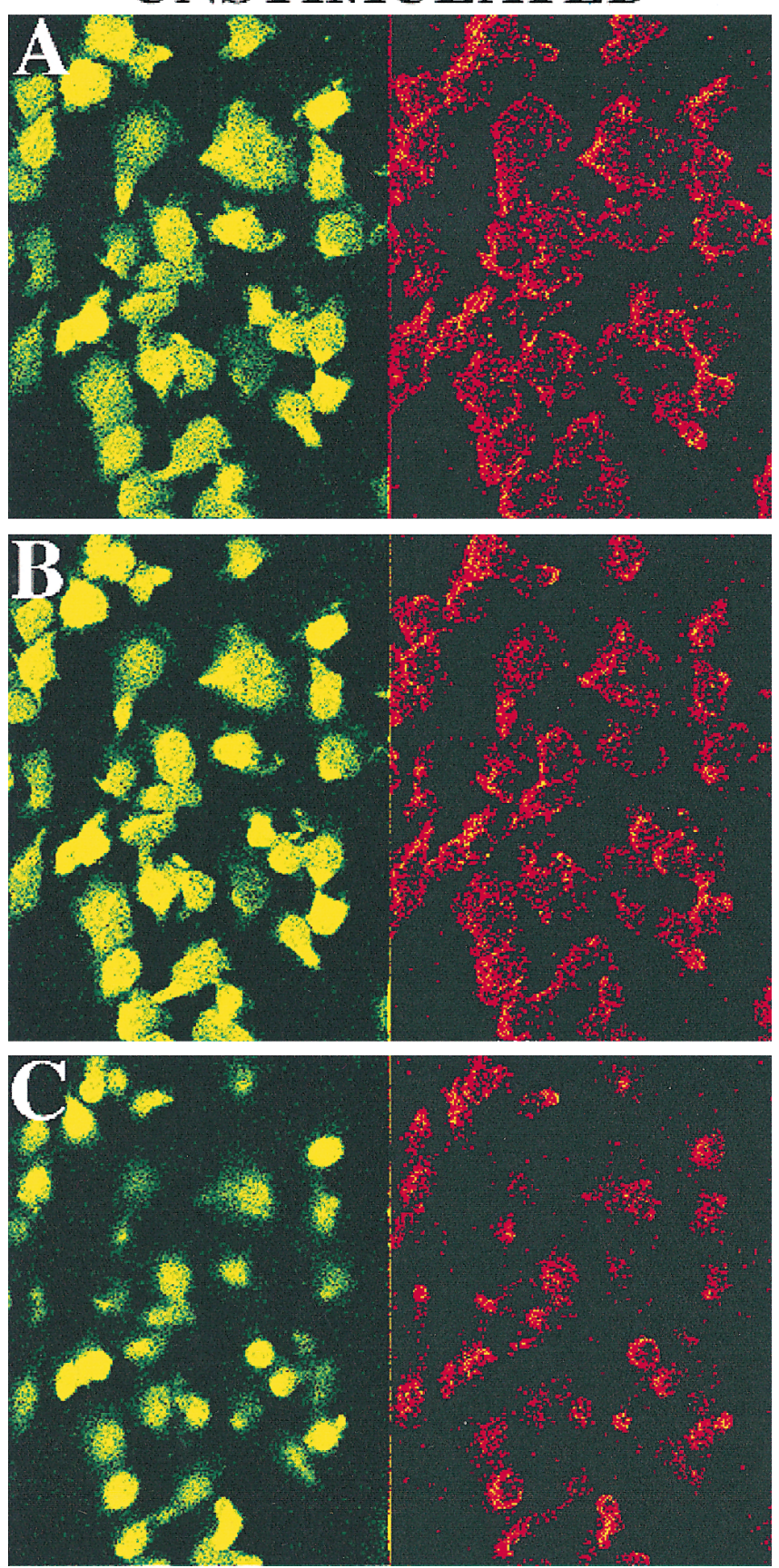

+RANTES
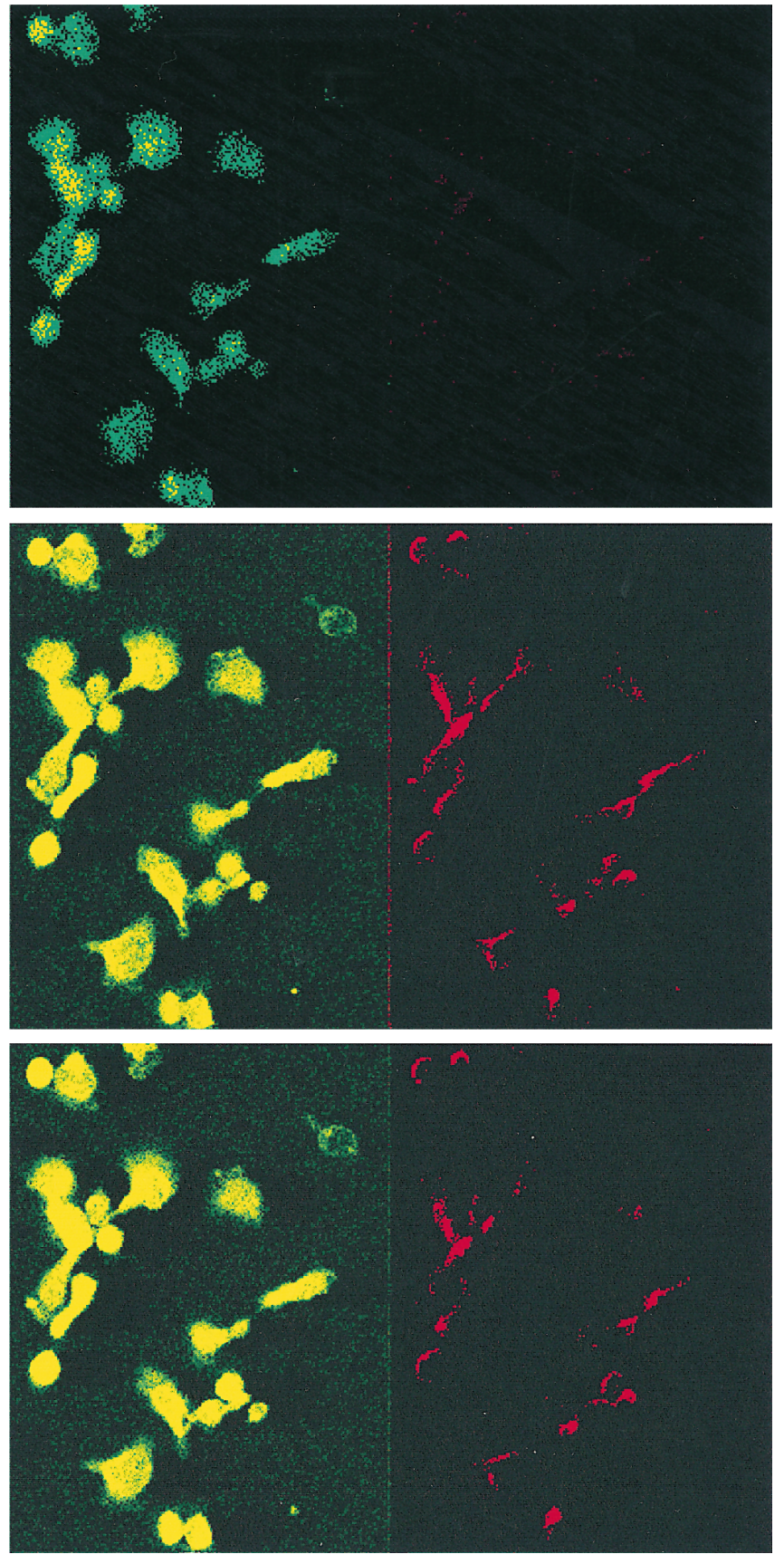

Figure 1. Cell uropods emerge away from the flattened cell bodies of adhered lymphocytes and are projected to the outer milieu. (a) Confocal fluorescence microscopy analysis of the spatial orientation of the uropod and ICAM-3 localization on T lymphoblasts adhering to ICAM-1-coated surfaces. T cells labeled with the fluorescence cytoplasmic probe CFDA-SE (green fluorescence) were allowed to bind to coverslips coated with $10 \mu \mathrm{g} / \mathrm{ml}$ of ICAM-1-Fc for $30 \mathrm{~min}$ at $37^{\circ} \mathrm{C}$ in the presence of the uropod inducing anti-ICAM-3 HP2/19 $\mathrm{mAb}(5 \mu \mathrm{g} / \mathrm{ml})$. Cells were then fixed and stained for ICAM-3 (red fluorescence) as described in Materials and Methods. Slides were analyzed by confocal laser scanning microscopy, and optical sectioning was adjusted to the plane of adhesion $(A$ and $B), 7(C$ and $D)$, and $10 \mu \mathrm{m}$ above $(E$ and $F)$. Optical sections correspond to $0.3 \mu \mathrm{m}$ in thickness. $(b)$ T lymphoblasts were allowed to adhere to ICAM-1 in the presence (right column) or in the absence (left column) of $10 \mathrm{ng} / \mathrm{ml}$ RANTES, and samples were processed as in $a$. Cytoplasmic (green fluorescence) and ICAM-3 membrane staining (red fluorescence) are shown. Optical sectioning was adjusted to the plane of adhesion $(A), 5(B)$, and $8 \mu \mathrm{m}$ above that plane $(C)$.

$\mathrm{CD} 45 \mathrm{R} 0^{+} \mathrm{T}$ cells were prepared by exhaustive negative selection from freshly isolated PBL using anti-CD45RO UCHL.1 or anti-CD45RA RP1/ $11 \mathrm{mAb}$, respectively, and immunomagnetic beads (Dynal Inc., Oslo, Norway) as described (Vartdal et al., 1987). Paired peripheral blood and syn- ovial fluid (SF) lymphocytes were obtained from patients with rheumatoid arthritis (Department of Rheumatology, Hospital de la Princesa, Madrid, Spain). Human T lymphoblasts were prepared from peripheral blood mononuclear cells by treatment with phytohemagglutinin (PHA) $0.5 \%$ (Phar- 
macia Fine Chemicals) for $48 \mathrm{~h}$. Cells were washed and cultured in RPMI 1640 (Flow Laboratories, Irvine, Scotland) containing 10\% FCS (Flow Laboratories) and $50 \mathrm{U} / \mathrm{ml}$ IL-2 (kindly provided by Eurocetus). T lymphoblasts cultured for 7-12 d were used in all experiments. T lymphoblasts have been extensively used to study $\mathrm{T}$ cell adhesion and activation (van Kooyk et al., 1991; Dransfield et al., 1992; Campanero et al., 1993). Melanoma cancer cells and autologous tumor infiltrating lymphocytes (TIL) were isolated from surgical specimens from patients with metastatic melanoma (Department of Pathology, Hospital Gregorio Marañón, Madrid, Spain). Tumor cells were grown in RPMI 1640/10\% FCS. TIL were cultured in AIM-V medium (GIBCO BRL, Life Technologies, Ltd., Paisley, Scotland) containing 4\% Ultroser HY (Sepracor Inc., SA, Villeneuve la Garenne, France) and $500 \mathrm{U} / \mathrm{ml}$ IL-2. The human dermal microvascular endothelial cell line HMEC-1 has previously been described (Ades et al., 1992) and was kindly provided by Drs. Ades and Lawley (Centers for Disease Control and Prevention and Emory University School of Medicine, Atlanta, GA). HMEC-1 were grown in MCDB 131 medium (GIBCO BRL) supplemented with 20\% FCS, 10 ng/ml EGF (Promega Biotech, Madison, WI), $1 \mu \mathrm{g} / \mathrm{ml}$ hydrocortisone (Sigma Chemical Co.), $20 \mathrm{mM}$ Hepes, and $10 \mathrm{mM}$ L-glutamine. Primary cultures of high endothelial cells (HEC) were established from cervical lymph nodes of $F_{1}$ hybrid rats, as previously described (Ager, 1987). HEC were grown in RPMI 1640 containing $20 \%$ FCS, and confluent cultures were serially passaged and split 1:2. For the experiments described herein, three different HEC cell lines between passage numbers 10 and 20 were used. Previous studies have shown that the interaction between lymphocytes and HEC is independent of the passage number of cell cultures (Ager and Mistry, 1988).

\section{Immunofluorescence and Digital Confocal Microscopy}

Immunofluorescence experiments were performed essentially as described (del Pozo et al., 1995). Briefly, 0.5-1 $\times 10^{6} \mathrm{~T}$ cells (PBL, SF lymphocytes, TIL, or lymphoblasts) were incubated in flat-bottomed, 24-well plates (Costar Corp.) in a final volume of $500 \mu \mathrm{l}$ complete medium on coverslips coated with different protein substrata or melanoma tumor cells. Chemokines $(10 \mathrm{ng} / \mathrm{ml})$, PMA $(20 \mathrm{ng} / \mathrm{ml})$, or $5 \mu \mathrm{g} / \mathrm{ml} \mathrm{HP} 2 / 19 \mathrm{mAb}$ was added, and cells were allowed to settle in a cell incubator at $37^{\circ} \mathrm{C}$ and $5 \%$ $\mathrm{CO}_{2}$ atmosphere. After different periods of time, cells were fixed with $3.7 \%$ formaldehyde in PBS for $10 \mathrm{~min}$ at room temperature and rinsed in TBS (50 mM Tris- $\mathrm{HCl}$, pH 7.6, $150 \mathrm{mM} \mathrm{NaCl}, 0.1 \% \mathrm{NaN}_{3}$ ). To visualize different membrane adhesion molecules, cells were stained with specific $\mathrm{mAb}$. After washing, cells were incubated with a 1:50 dilution of an FITClabeled rabbit $\mathrm{F}\left(\mathrm{ab}^{\prime}\right)_{2}$ anti-mouse IgG (Pierce, Rockford, IL) or a 1:500 dilution of a Cy3-goat anti-mouse IgG (Amersham Life Science, Pittsburgh, PA). The cells were observed using a Nikon Labophot-2 photomicroscope with 40,60 , and $100 \times$ oil immersion objectives. The proportion of uropod-bearing cells was calculated by random choice of 10 different fields $(60 \times$ objective) of each condition and direct counting of total cells (400-500) and uropod-bearing cells. Preparations were photographed on either Ektachrome 400 (color pictures) or TMAX 400 (black and white) film (Kodak Co., Rochester, NY). The latter was processed to 800-1,600 ASA with TMAX developer (Kodak Co.).

Samples for confocal microscopy were prepared as for standard immunofluorescence studies. T lymphoblasts were cytoplasmically labeled with the fluorescent probe CFDA-SE, following manufacturer's instructions (Molecular Probes Europe BV, Leiden, The Netherlands). Labeled T lymphoblasts were incubated in flat-bottomed, 24-well plates (Costar Corp.) in a final volume of $500 \mu \mathrm{l}$ complete medium on coverslips coated with $10 \mu \mathrm{g} / \mathrm{ml}$ ICAM-1-Fc or a confluent monolayer of EC. Chemokines, control antibody (P3X63), or the anti-ICAM-3 TP1/24 or HP2/19 mAb (5 $\mu \mathrm{g} / \mathrm{ml}$ ) was added, and cells were allowed to settle in a cell incubator at $37^{\circ} \mathrm{C}$ and $5 \% \mathrm{CO}_{2}$ for $1 \mathrm{~h}$. Cells were then fixed with $3.7 \%$ formaldehyde in PBS for $10 \mathrm{~min}$ at room temperature and rinsed in TBS $(50 \mathrm{mM}$ Tris- $\mathrm{HCl}$, pH 7.6, $150 \mathrm{mM} \mathrm{NaCl}, 0.1 \% \mathrm{NaN}_{3}$ ). After washing, cells were incubated with a 1:50 dilution of a Texas red-conjugated goat $\mathrm{F}\left(\mathrm{ab}^{\prime}\right)_{2}$ anti-mouse IgG (Caltag Laboratories, So. San Francisco, CA). Confocal microscopy analysis was performed using the confocal laser scanning system (MRC1000; Bio-Rad Laboratories Ltd., Hertfordshire, U.K.) and a Nikon Diaphot 200 inverted microscope. Images of serial cellular sections were acquired with the BioRad CoMos graphical user-interface and subsequently processed to obtain three-dimentional reconstructions using the VoxelView (Vital Images, Inc., Fairfield, IA) software on an Indigo computer workstation.

Tissue distribution of ICAM-3-bearing lymphocytes was determined using double immunofluorescence staining. Surgical biopsy specimens were snap frozen in liquid nitrogen. $4 \mu \mathrm{m}$ frozen sections were cut, air dried, and acetone fixed. Sections were overlaid with mAb supernatants and incubated for $30 \mathrm{~min}$ at room temperature in a humidified chamber. After two washings in TBS, a 1:50 dilution of Cy3-goat anti-mouse IgG was added. After washing, the sections were saturated with $10 \%$ nonspe-
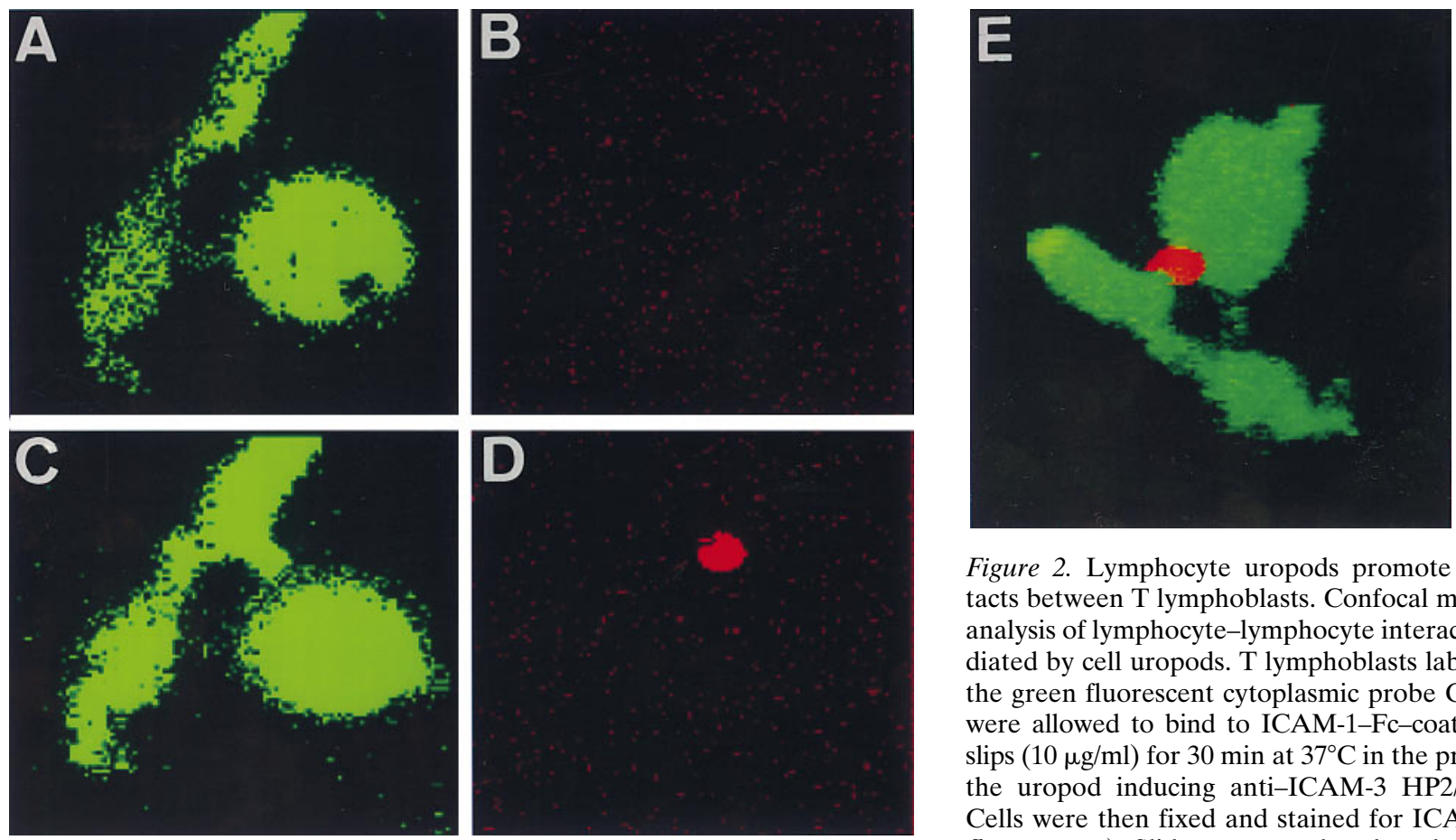
the three-dimensional reconstruction of cells, simultaneously showing the cytoplasmic (green) and ICAM-3 (red) staining. 
cific mouse serum in TBS. To stain T lymphocytes, FITC-conjugated Leu 4 anti-CD3 mAb was used (Becton Dickinson, San Jose, CA). After washing, the sections were mounted in Mowiol (Calbiochem-Novabiochem, La Jolla, CA), and confocal microscopy analysis of serial tissue sections was carried out.

\section{Time-Lapse Videomicroscopy}

Video microscopy analysis was performed using a Nikon Diaphot 300 inverted microscope equipped with a Sony SSC-M350CE CCD black and white videocamera coupled to a Sony SVT-5000P time lapse videocassette recorder and a Sony PVM-1453MD video monitor. T cells (PBL, SF lymphocytes, TIL, or lymphoblasts) were incubated for $30 \mathrm{~min}$ at $37^{\circ} \mathrm{C}$ in 35-mm plastic petri dishes (Costar Corp.) previously coated with VCAM-1, ICAM-1 $(10 \mu \mathrm{g} / \mathrm{ml})$, or melanoma tumor cells from a patient, in the presence of chemokines, PMA, or anti-ICAM-3 TP1/24 or HP2/19 mAb. After addition of a second cohort of T cells, cell-cell interactions were filmed for $1 \mathrm{~h}$ under phase contrast using a $20 \times$ objective. Where indicated, cells of either the first or the second cohort were previously incubated for additional $15 \mathrm{~min}$ at $37^{\circ} \mathrm{C}$ with different blocking mAbs. Images were acquired every $3.2 \mathrm{~s}$, and sequential frames were photographed. In each experimental condition, the number of cells that were attached, spread, and moving on the substrate (phase-dark cells), as well as the number of cell-cell interactions between the uropod of adhered cells and lymphocytes from the second cohort (phase-bright cells), was counted. The recruitment index was expressed as number of cells of the second cohort being captured per number of cells of the first layer adhered to the substrate.

\section{HMEC-1 Culture on Transwell Inserts and Monolayer Integrity Testing}

T lymphoblast migration through a confluent monolayer (HMEC-1) was assayed in a Transwell cell culture chamber (Costar Corp.). The chemo-
A

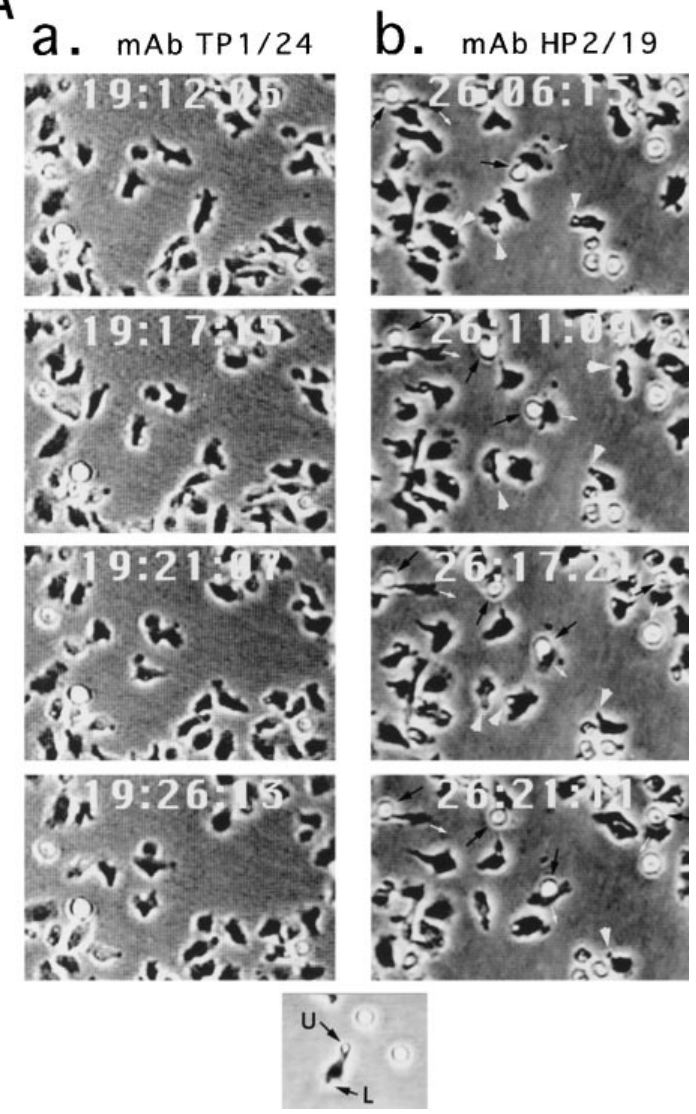

B
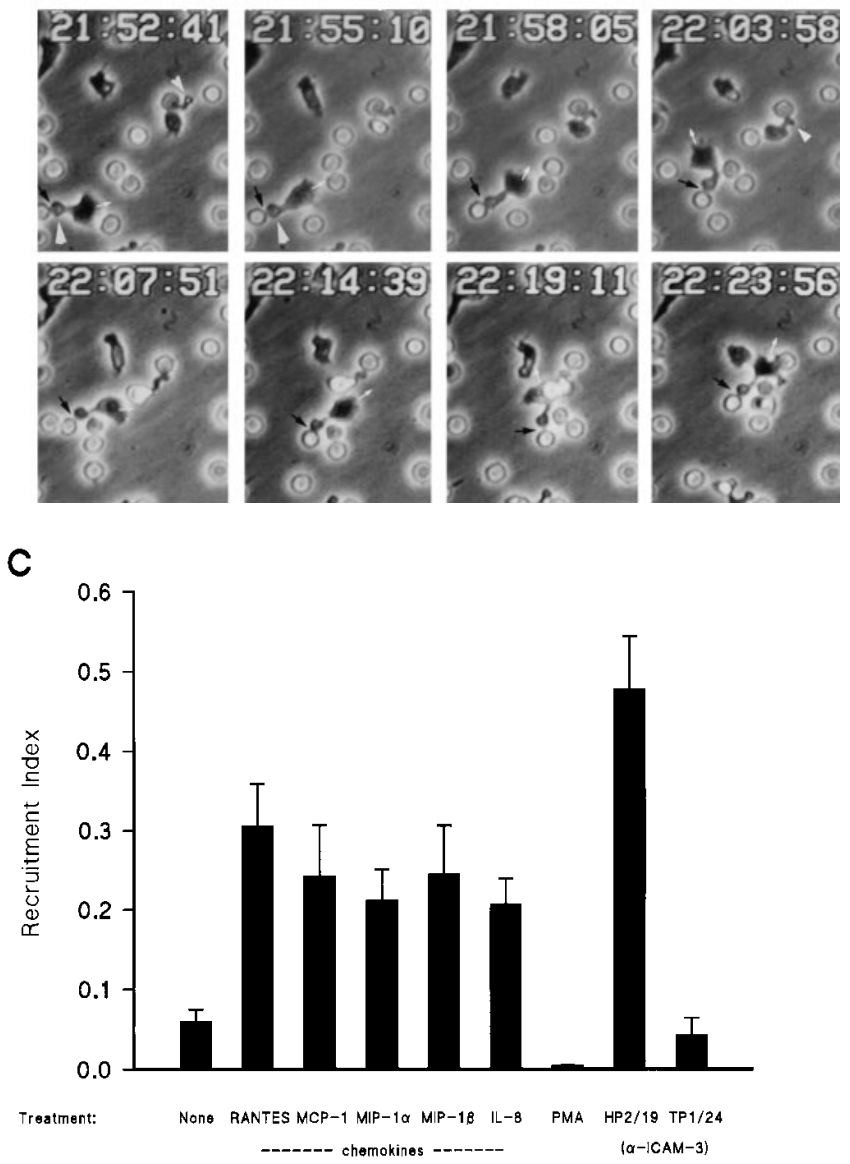

Figure 3. T cells are recruited by uropod-bearing $\mathrm{T}$ lymphocytes. Time-lapse videomicroscopy analysis of lymphocyte-lymphocyte interactions. ( $A$ and $B$ ) The chemokine RANTES and the uropod-inducing anti-ICAM-3 HP2/19 mAb induce T cells to contact, capture, and transport other T cells through their uropods. T lymphoblasts were allowed to bind to plastic petri dishes coated with ICAM-1-Fc and treated with the anti-ICAM-3 uropod-inducing mAb HP2/19 (Ab, $5 \mu \mathrm{g} / \mathrm{ml})$, with the isotype-matched nonuropod inducing antiICAM-3 TP1/24 (Aa, $5 \mu \mathrm{g} / \mathrm{ml}$ ), or with $10 \mathrm{ng} / \mathrm{ml}$ RANTES $(B)$ for $30 \mathrm{~min}$ at $37^{\circ} \mathrm{C}$. After addition of a second cohort of untreated T lymphocytes (exhibiting a phase-bright appearance readily distinguishable from the phase-dark cells of the first cohort), cell-cell interactions were filmed with a time-lapse videocassette recorder for $1 \mathrm{~h}$. Time frames obtained from videotape recording of one representative experiment are shown. White arrowheads point to uropods displayed by phase-dark cells of the first layer; black arrows indicate phasebright $\mathrm{T}$ lymphocytes captured by uropod-bearing cells, while the small white arrows mark the direction of movement of the adhered cell. (Inset) Polarized lymphocyte migrating on ICAM-1-coated surface, showing the phase-dark leading edge $(L)$ and the phase-bright uropod $(U) .(C)$ Measurement of cell recruitment mediated by cell uropods. T lymphoblasts were allowed to bind to plastic petri dishes coated with VCAM-1-Fc for $30 \mathrm{~min}$ at $37^{\circ} \mathrm{C}$ in the presence of medium alone, $10 \mathrm{ng} / \mathrm{ml}$ RANTES, MCP-1, MIP- $1 \alpha$, MIP-1 $\beta$, IL- $8,20 \mathrm{ng} /$ $\mathrm{ml}$ PMA, or $5 \mu \mathrm{g} / \mathrm{ml}$ anti-ICAM-3 HP2/19 and TP1/24 mAb. After addition of a second cohort of T cells, cell-cell interactions were recorded for $1 \mathrm{~h}$, and the recruitment index was estimated as described in Materials and Methods. Arithmetic mean $\pm 1 \mathrm{SD}$ of three independent experiments is shown. 
A

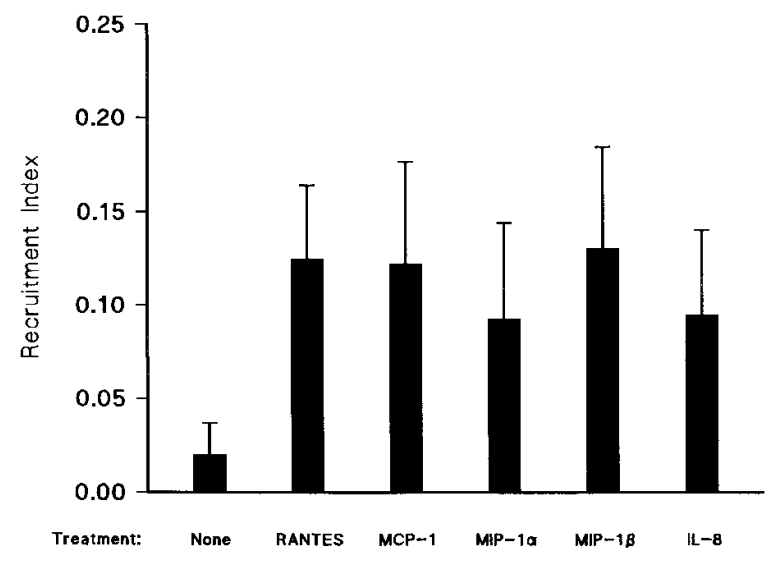

B

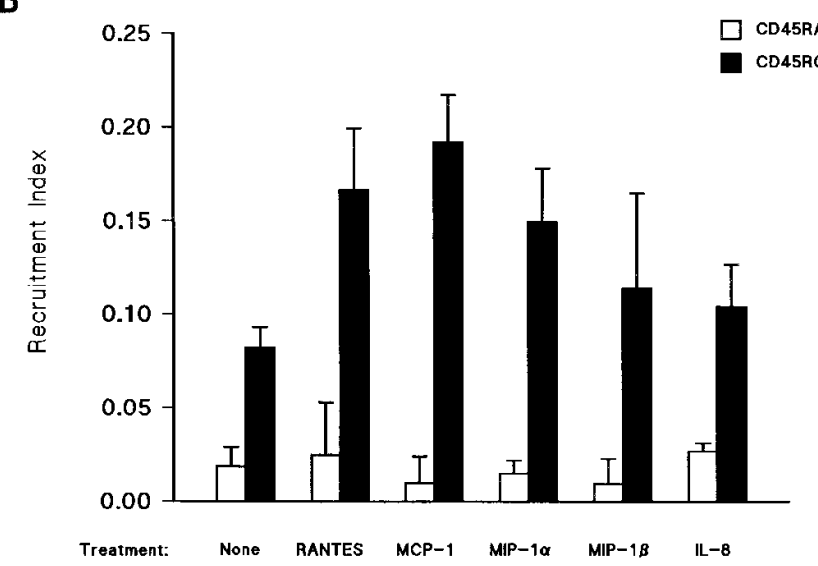

C
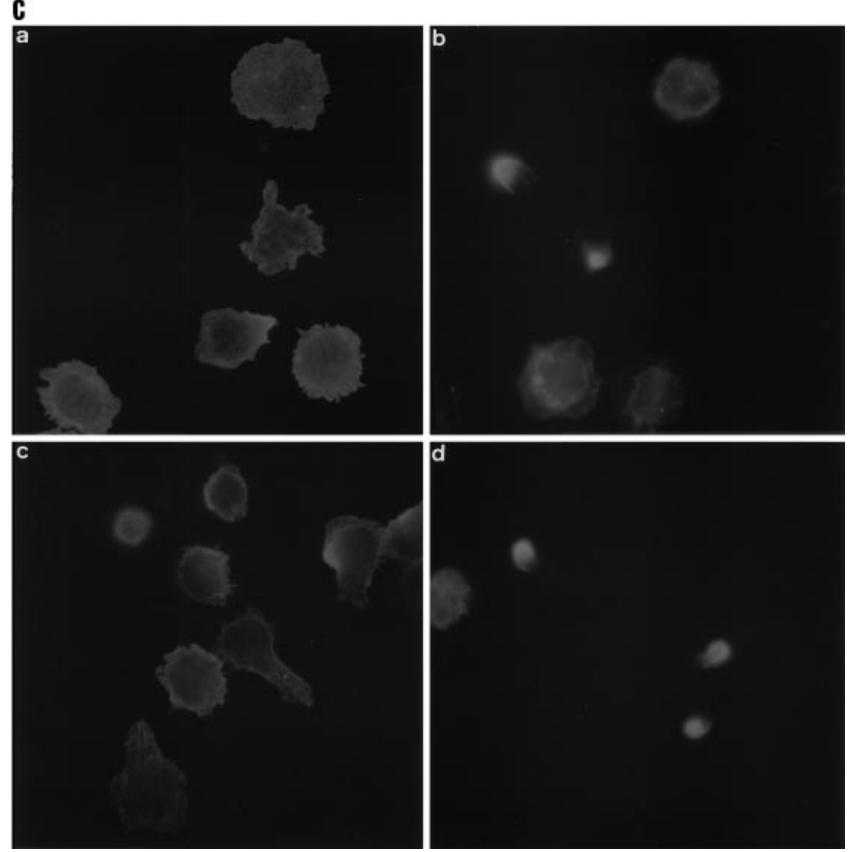

Figure 4. Freshly isolated $\mathrm{CD} 45 \mathrm{RO}^{+}$lymphocytes are able to recruit cells through the uropod. ( $A$ and $B$ ) Measurement of cell recruitment mediated by cell uropods. The total population of PBL

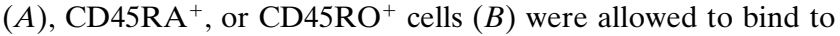
plastic petri dishes coated with ICAM-1-Fc for $30 \mathrm{~min}$ at $37^{\circ} \mathrm{C}$ in the presence of medium alone, $10 \mathrm{ng} / \mathrm{ml}$ RANTES, MCP-1, MIP- taxis chambers are separated by a polycarbonate membrane $(6.5 \mathrm{~mm}$ diam, $10 \mu \mathrm{m}$ thickness and 8 - $\mu \mathrm{m}$-diam pore size). Filters were coated on their upper surface with fibronectin and layered with HMEC-1. The lower well of the chamber was filled with HMEC-1 culture medium. The integrity of the endothelial barrier was assessed by diffusion of a trypan bluealbumin complex across the endothelial monolayer as described (Rotrosen and Gallin, 1986). Only cell monolayers with permeability $\leqslant 0.5 \%$ were used for the transendothelial migration assays.

\section{T Lymphoblast Transendothelial Migration Assay}

All assays were performed in triplicate or quadruplicate chambers, with $\mathrm{T}$ cells from a single donor and HMEC-1-covered Transwell filters from the same batch. T lymphoblasts were poured at different concentrations to the upper compartment of the chamber in the presence of either antiICAM-3 mAbs TP1/24 (IgG $2 \mathrm{a})$ or HP2/19 $\left(\operatorname{IgG}_{2 \mathrm{a}}\right)$ at $5 \mu \mathrm{g} / \mathrm{ml}$ for $30 \mathrm{~min}$ at $37^{\circ} \mathrm{C}$ in a $5 \% \mathrm{CO}_{2}$ atmosphere. Unbound $\mathrm{T}$ cells were removed, and a second cohort of $10^{6}{ }^{51} \mathrm{Cr}$-labeled $\mathrm{T}$ lymphoblasts was added to the upper compartment of the chamber. After different periods of time (5 min-6 h), the percentage of cells that migrated across the endothelial cell layer was calculated related to the total input of ${ }^{51} \mathrm{Cr}$-labeled $\mathrm{T}$ cells. In some experiments, after the induction of the uropod formation, cells of the first cohort were incubated for additional $15 \mathrm{~min}$ with different blocking mAbs. Where indicated, lymphocytes were pretreated either with $10 \mathrm{mM}$ butanedione monoxime or with $20 \mu \mathrm{M}$ colchicine for $30 \mathrm{~min}$ at $37^{\circ} \mathrm{C}$, extensively washed, and used as described above.

\section{Microscope Assay for Lymphoblast Transmigration Across HEC Layers}

HEC were grown to confluence in polystyrene tissue culture chamber slides (Nunc A/S, Roskilde, Denmark). Aliquots of T lymphoblasts were incubated with different $\mathrm{mAb}(5 \mu \mathrm{g} / \mathrm{ml})$ during $15 \mathrm{~min}$ at $37^{\circ} \mathrm{C}$, washed, and poured onto HEC layers. After incubating for different periods of time, unbound lymphocytes were removed by aspiration, and the HEC layers were washed four times in prewarmed HBSS containing $1 \%$ FBS, fixed (1\% glutaraldehyde in PBS for $20 \mathrm{~min}$ ), and stained with $1 \%$ toluidine blue. Slides were examined by two independent observers using a Nikon Labophot- 2 photomicroscope with a $60 \times$ objective. Previous studies have shown that surface-bound lymphocytes (small, round, and darkblue cells) and transmigrated cells (large, flattened, and light-blue cells) can be easily distinguished in these slides (Ager and Mistry, 1988). All assays were run in triplicate, and the number of lymphocytes of each type was counted in three separate fields. The migration index was calculated as follows: number of transmigrated cells/number of cells. Preparations were photographed using Ektachrome 400 color film (Kodak Co.).

\section{Immunofluorescence Flow Cytometry Analysis}

$\mathrm{T}$ cells were collected before and $5 \mathrm{~h}$ after transendothelial migration, incubated at $4^{\circ} \mathrm{C}$ for $30 \mathrm{~min}$ in PBS with the primary mAb, and washed two

$1 \alpha$, MIP-1 $\beta$, or IL-8. After addition of a second cohort of PBL from the same donor, cell-cell interactions were recorded for $1 \mathrm{~h}$, and the recruitment index was estimated as described in Materials and Methods. Arithmetic mean $\pm 1 \mathrm{SD}$ of four independent experiments performed with $\mathrm{PBL}(A)$ or two independent ones with $\mathrm{CD}^{2} 5 \mathrm{RA}^{+} / \mathrm{CD} 45 \mathrm{RO}^{+}$cells $(B)$ is shown. $(C)$ Freshly isolated $\mathrm{CD}_{45 \mathrm{RA}^{+}}(a$ and $c)$ or $\mathrm{CD}^{2} 5 \mathrm{RO}^{+}(b$ and $d)$ cells were allowed to bind to coverslips coated with $10 \mu \mathrm{g} / \mathrm{ml}$ ICAM-1-Fc for $30 \mathrm{~min}$ at $37^{\circ} \mathrm{C}$ in the presence ( $c$ and $d$ ) or in the absence ( $a$ and $b)$ of $10 \mathrm{ng} / \mathrm{ml} \mathrm{MIP-1} \alpha$. Fixed cells were then stained for ICAM-3 with TP1/24 mAb, and the proportion of uropod-bearing cells was calculated as described in Materials and Methods. The percentage of polarized cells in CD45RA ${ }^{+}$versus $\mathrm{CD}^{2} 5 \mathrm{RO}^{+}$cells was as follows: untreated 5 vs $19 \%$, RANTES 11 vs $29 \%$, MCP-1 10 vs $32 \%$, MIP- $1 \alpha 3$ vs $26 \%$, MIP- $1 \beta 4$ vs $22 \%$, and IL- 88 vs $20 \%$. The cellular uropod and the cell contact area with the substratum were indeed in a distinct plane of focus. 
a

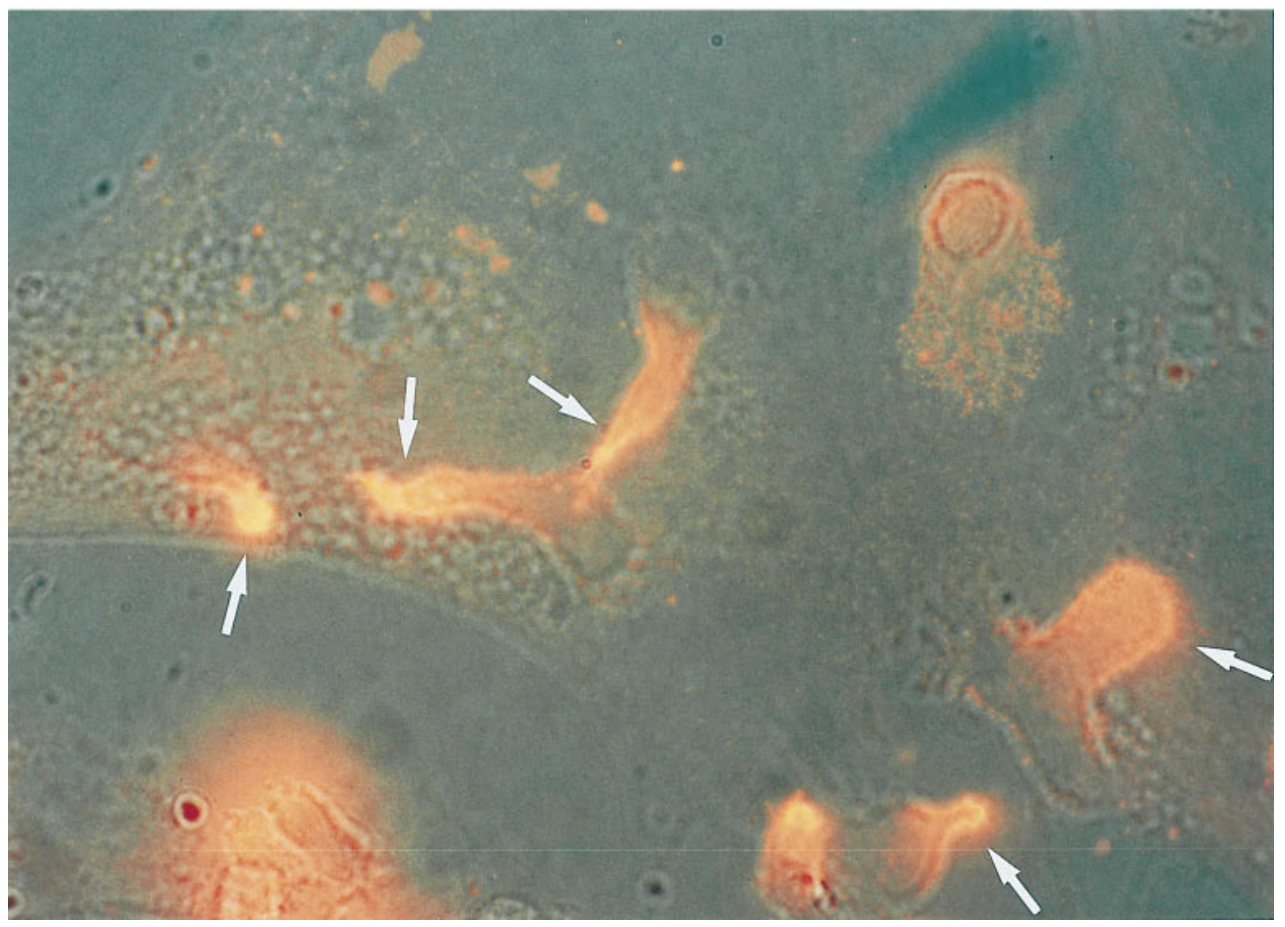

b

\section{3}
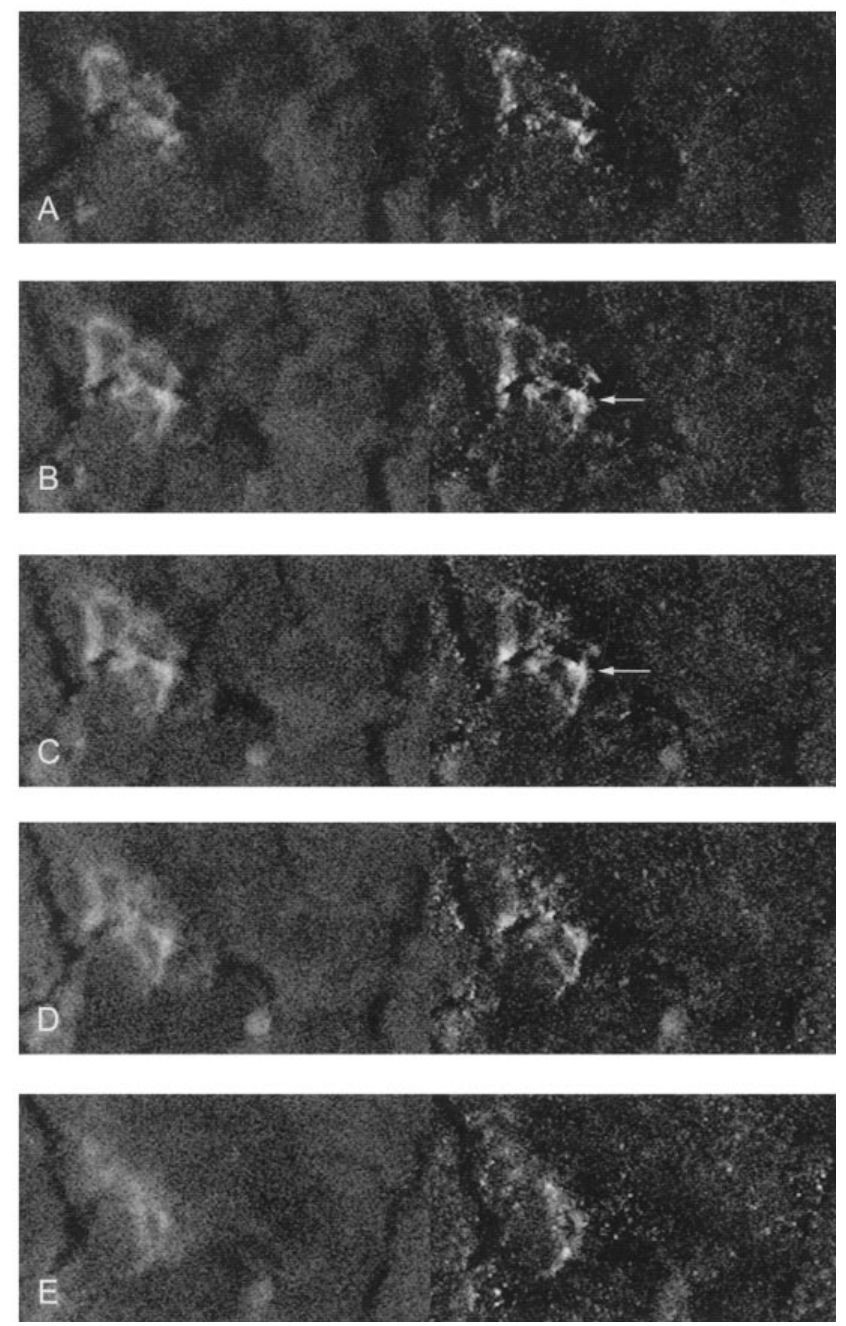

Figure 5. Lymphocyte polarization occurs in vivo. (a) Lymphocyte polarization and ICAM-3 redistribution to the cellular uropod during TIL binding to autologous melanoma tumor cells. TIL were cocultured with a monolayer of melanoma cells from the same patient for $1 \mathrm{~h}$ at $37^{\circ} \mathrm{C}$. Fixed cells were then stained for ICAM-3 with TP1/24 mAb followed by incubation with a Cy3-goat anti-mouse $\mathrm{IgG}$, as described in Materials and Methods. Epifluorescent and bright field conditions were photographed on the same frame by double exposure. Arrows point to uropods. (b) Tissue distribution of ICAM-3 in $\mathrm{T}$ lymphocytes that infiltrate a tumor specimen. A tissue section of a lung metastatic melanoma biopsy was double immunofluorescence stained for ICAM-3 (red fluorescence) and CD3 (green fluorescence) as described in Materials and Methods. Tissue sections were analyzed by confocal laser scanning microscopy. Serial optical sections of $0.5 \mu \mathrm{m}$ thick are shown (from $A$ to $E$ ). A small aggregate of three lymphocytes connected through the tissue is followed. Arrows point out the area of cell-cell contact where ICAM-3 is concentrated. 
times, and then FITC-conjugated goat anti-mouse $\mathrm{F}\left(\mathrm{ab}^{\prime}\right)_{2}$ (Caltag Laboratories) was used as secondary antibody. The fluorescence of 2,000 cells was measured on a FACS ${ }^{\circledR}$ can (Becton Dickinson) using Lysis II software.

\section{Results}

\section{Spatial Orientation of the Cellular Uropod and ICAM-3 Distribution}

To assess the spatial disposition of the cellular uropod and the membrane distribution of ICAM-3, confocal microscopy analysis of fluorescent-labeled (green fluorescence) T lymphoblasts, adhering to immobilized ICAM-1 was carried out in the presence of the uropod-inducing antiICAM-3 HP2/19 mAb. This mAb was employed since it is able to mimic the effect caused by chemokines on uropod formation (Campanero et al., 1994). We found that no ICAM-3 signal (red fluorescence) was detected in the area of contact between cells and protein substrate (Fig. $1 a, A$ and $B$ ). Interestingly, ICAM-3 fluorescence gradually increased on upper planes of uropods, displaying the highest intensity at a distance of $7-10 \mu \mathrm{m}$ from the plane of the coverslip, coincident with the tips of uropods (Fig. $1 a$, $C-F$ ). Similar results were obtained in experiments in which T cells were adhered to EC instead of ICAM-1 (data not shown). Moreover, the same morphological changes and ICAM-3 surface redistribution effect were observed by using chemokines. Unstimulated lymphoblasts were also stained as controls (Fig. $1 \mathrm{~b}$ ). Hence, these results show that uropods extend away from the large flattened area of cell contact with the substratum, being well exposed to the outer milieu.

\section{The Cellular Uropod Promotes Cell-Cell Contacts in T Lymphoblasts}

The projection of uropod towards outer milieu and its high content of several adhesion molecules further suggested its involvement in the recruitment of free lymphocytes. To address this point we carried out a confocal microscopy analysis of the contacts that occur between adhered, uropod-bearing lymphocytes and other $\mathrm{T}$ cells. Interestingly, we found that the anchorage between those cells was located $5 \mu \mathrm{m}$ above of the plate level and that it was mediated by the ICAM-3-bearing uropod of one cell (Fig. 2, $A-D)$. Three-dimensional reconstruction of all different optical sections of the specimen and rotation of the image clearly confirmed that the intercellular contact was mediated by the uropod (Fig. 2 E). Similar cell-cell contacts were observed when the uropod was induced by the relevant physiological stimuli, the chemokines (Fig. $1 b$ ).

\section{T Cells Are Able to Recruit and Transport Other Cells Through Their Uropods}

Since confocal microscopy analysis only provided a static view of the possible functional role of uropod, we decided to undertake a dynamic assessment of this issue through a time-lapse phase contrast microscopy analysis. A first layer of T cells was allowed to attach to and spread on an ICAM-1-coated surface, and then these cells were induced to develop uropods with the HP2/19 anti-ICAM-3

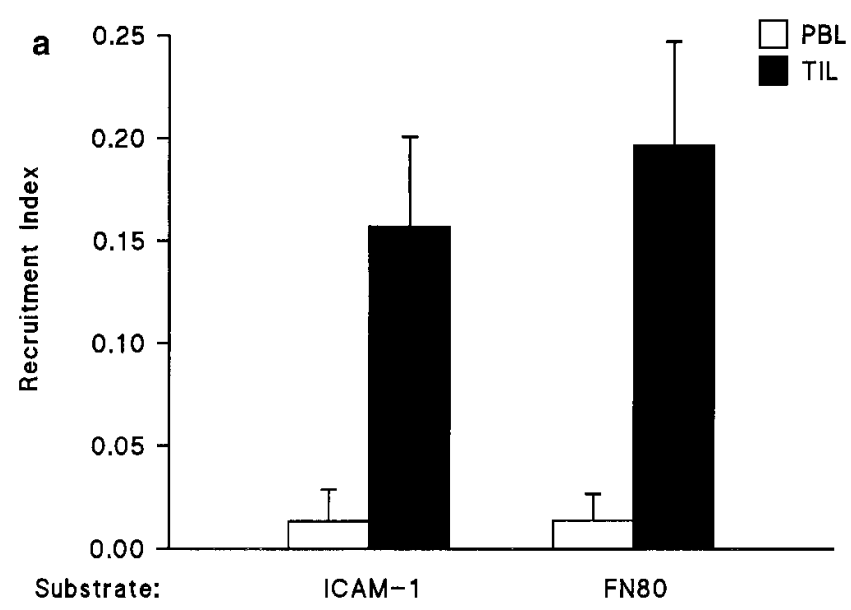

b
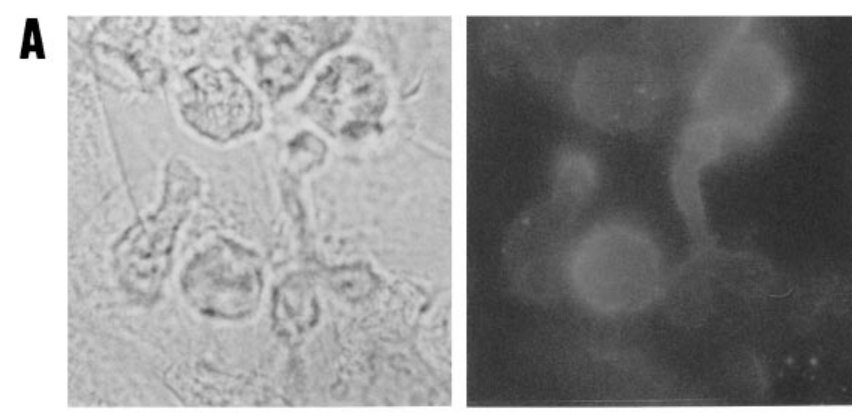

B
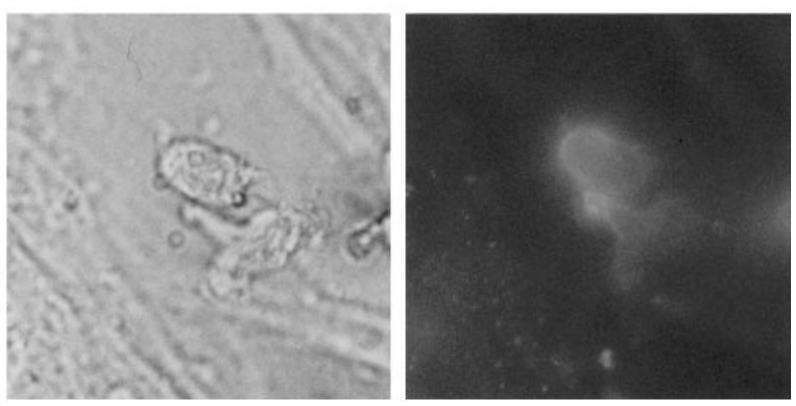

Figure 6. TIL are able to recruit cells through the uropod. (a) PBL or TIL were allowed to bind to plastic petri dishes coated with $10 \mu \mathrm{g} / \mathrm{ml} \mathrm{ICAM}-1-\mathrm{Fc}$ or $20 \mu \mathrm{g} / \mathrm{ml} \mathrm{FN80} \mathrm{for} 30 \mathrm{~min}$ at $37^{\circ} \mathrm{C}$. After addition of a second cohort of PBL, cell-cell interactions were recorded for $1 \mathrm{~h}$, and the recruitment index was estimated as described in Materials and Methods. Arithmetic mean $\pm 1 \mathrm{SD}$ of three independent experiments performed with PBL and TIL from three different donors is shown. In parallel, lymphocytes were allowed to adhere to coverslips coated with $10 \mu \mathrm{g} / \mathrm{ml}$ ICAM-1-Fc for $30 \mathrm{~min}$ at $37^{\circ} \mathrm{C}$, fixed, and stained for ICAM-3, and the proportion of uropod-bearing cells was calculated as described in Materials and Methods: on ICAM-1, PBL 3\%, TIL 17\%; on FN80, PBL 5\%, TIL 23\%. (b) TIL were allowed to bind to plastic petri dishes coated with a monolayer of melanoma cells from the same patient for $1 \mathrm{~h}$ at $37^{\circ} \mathrm{C}$. A second cohort of PBL was added, and after $1 \mathrm{~h}$ of incubation the specimens were fixed and stained for ICAM-3 with TP1/24 mAb as described in Materials and Methods. Same fields from two different specimens $(A$ and $B)$ were photographed under bright field (left column) and epifluorescent (right column) conditions. 
mAb or different chemokines. A second cohort of T cells was then added, and cell-cell interactions were filmed. Attached lymphocytes in the first cohort adopted a phasedark morphology. Under conditions of uropod induction, a significant proportion of cells of the second cohort, which exhibited a phase-bright appearance readily distinguishable from the first cohort, were contacted, trapped, and finally engaged by cells of the first cohort (Fig. 3, $A$ and $B$ ). Interestingly, the adhered lymphocytes of the first cohort were moving on the ICAM-1-coated surface, displaying the uropod in the antipodean pole relative to the advancing front of the cell, and were transporting other $\mathrm{T}$ cells engaged through the uropod (Fig. $3 B$ ). By counting the number of cells of the second cohort that were recruited by cells of the first layer, it was estimated that the induction of the uropod resulted in a 5-10-fold increase in cell recruitment (Fig. $3 C$ ). In contrast, other stimulating agents, such as phorbol esters, that promote integrin activation but are unable to trigger uropod formation, failed to stimulate $\mathrm{T}$ cell recruitment (Fig. $3 \mathrm{C}$ ), thus underlining the participation of uropods in this phenomenon.

\section{Selective Recruitment of T Cells by Peripheral Blood CD45RO ${ }^{+}$Memory and In Vivo Activated T Lymphocytes}

Although T lymphoblasts likely represent the memoryactivated subset of $\mathrm{T}$ cells, the number of circulating lymphoblasts is very low. Therefore, we explored whether the mechanism of cell recruitment mediated by uropods could be observed in lymphocytes directly isolated from the blood. Although these cells adhered nicely onto the ICAM-1coated surface, they moved less than activated T lymphoblasts, and chemokines only weakly induced lymphocyte polarization and recruitment of a second layer of unstimulated peripheral blood lymphocytes (Fig. $4 A$, and data not shown). Therefore, we decided to explore whether the recruitment was selectively exerted by a subset of the cells. In this regard, it has recently been reported that most of the chemokine receptors are upregulated on the CD45R $0^{+}$ memory-activated phenotype cells (Loetscher et al., 1996; Mackay, 1996; Qin et al., 1996). Thus, we isolated CD45RA ${ }^{+}$ naive and $\mathrm{CD} 45 \mathrm{R} 0^{+}$memory peripheral blood lymphocytes and compared their ability to contact, engage, and drive other lymphocytes. Chemokine-mediated T cell recruitment was much more efficiently promoted by $\mathrm{CD} 45 \mathrm{R} 0^{+}$ cells than by $\mathrm{CD}_{45 \mathrm{RA}^{+}}$naive cells (Fig. $4 \mathrm{~B}$ ). Accordingly, $\mathrm{CD} 45 \mathrm{R}^{+}$showed a higher polarized morphology, both in basal conditions and after chemokine treatment (Fig. $4 C, b$ and $d$ ). $\mathrm{CD} 45 \mathrm{R} 0^{+}$cells developed a proper uropod, and they actively locomote on the ICAM-1-coated surface, whereas the CD45RA ${ }^{+}$cells only displayed a capping of the ICAM-3 molecule and migrated slower (Fig. $4 C$ and data not shown). These data indicate that CD45R0 ${ }^{+}$ memory $\mathrm{T}$ cells responded more efficiently to chemokines likely due to the higher expression of chemokine receptors on these cells and therefore can account for the $\mathrm{T}$ cell recruitment observed in the total population of freshly isolated lymphocytes.

We also studied lymphocyte recruitment with physiologically in vivo TIL. These lymphocytes, which infiltrate different tumors, display an in vivo activated phenotype $\left(\mathrm{CD} 45 \mathrm{R}^{+} \mathrm{CD}^{+} 9^{+}\right)$and high levels of cytotoxicity against autologous tumor cells (Itoh et al., 1988). Freshly prepared TIL adhered to autologous melanoma tumor cells displayed a polarized morphology with ICAM-3 redistribution to the cell uropod (Fig. $5 a$ ). Moreover, TIL were found to be polarized, and ICAM-3 was found to be con-
A

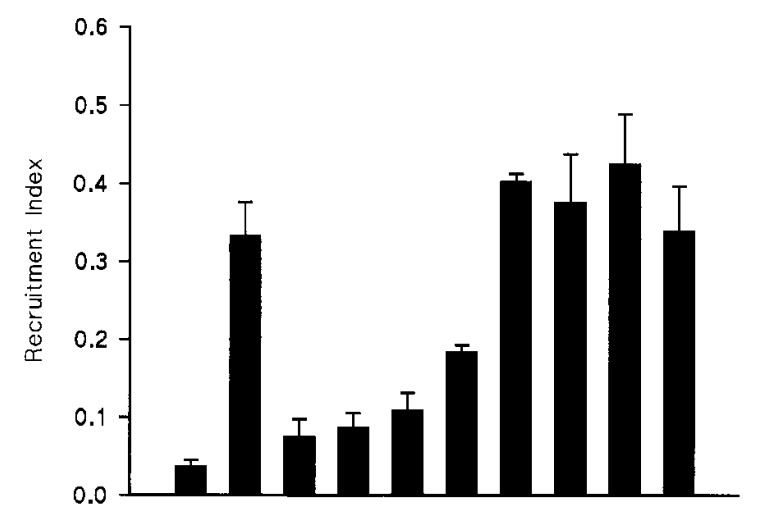

B
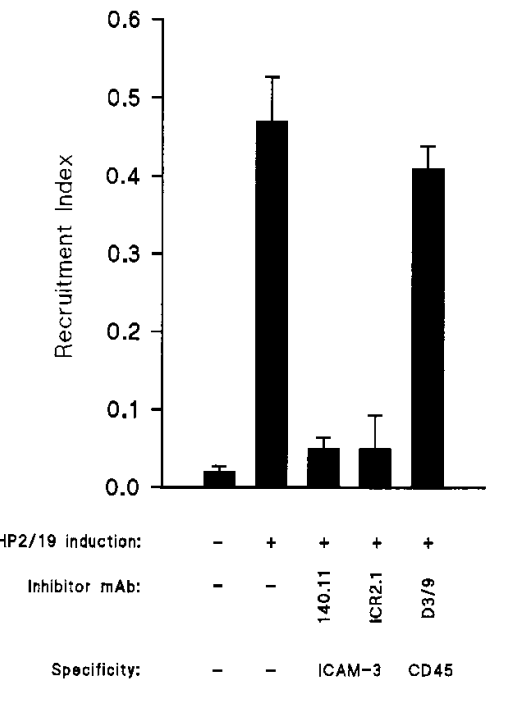

Figure 7. Involvement of ICAM-1 and -3 in lymphocyte recruitment mediated by cell uropods. $(A)$ T lymphoblasts adhered for $30 \mathrm{~min}$ at $37^{\circ} \mathrm{C}$ to VCAM-1-Fc coated surfaces in the presence of 10 $\mathrm{ng} / \mathrm{ml}$ RANTES were then incubated for $15 \mathrm{~min}$ with the blocking mAb anti-ICAM-3 140.11, anti-ICAM-1 Hu5/3, anti-CD43 TP1/36, antiCD44 HP2/9, or anti-CD45 D3/9 before the addition of a second cohort of $\mathrm{T}$ cells. Where indicated, the latter cells were pretreated for 15 min with the anti- $\beta 2$ integrin $\mathrm{Lia} 3 / 2 \mathrm{mAb}$, the anti-CD11a YTH81.5 mAb, or the antiL-selectin LAM1-3 mAb before addition to the first layer of T cells. The recruitment index was calculated. Arithmetic mean $\pm 1 \mathrm{SD}$ of three independent experiments is shown. (B) Cells were allowed to adhere for $30 \mathrm{~min}$ at $37^{\circ} \mathrm{C}$ to ICAM-1-Fc coated petri dishes in the presence of the anti-ICAM-3 uropod-inducing $\mathrm{mAb} \mathrm{HP} 2 / 19$ and additionally incubated for $15 \mathrm{~min}$ at $37^{\circ} \mathrm{C}$ either with the blocking anti-ICAM-3 mAbs 140.11 or ICR2.1 or with the anti-CD45 D3/9 mAb before addition of the second cohort of T cells. Arithmetic mean \pm 1 SD of two independent experiments is shown. 
centrated in the area of cell contact in the small aggregates of $\mathrm{T}$ cells that infiltrate the melanoma tissue sections (Fig. $5 \mathrm{~b}$ ). TIL were able to induce $\mathrm{T}$ cell recruitment when adhered to either ICAM-1- or FN80-coated surfaces (Fig. $6 a$ ); this phenomenon was also observed when TIL adhered to a monolayer of the tumor cells that these lymphocytes infiltrated in vivo (Fig. $6 \mathrm{~b}$ ). Additionally, we also explored the in vivo relevance of this phenomenon in the inflammatory disease rheumatoid arthritis. Lymphocytes isolated from either peripheral blood or synovial fluid of these patients were polarized when adhered to ICAM-1 (20 and $77 \%$, respectively) and consequently, were able to recruit peripheral blood lymphocytes of the same patient (recruitment indexes: 0.13 and 0.37 , respectively).

\section{Involvement of ICAM-1 and ICAM-3 in Lymphocyte Recruitment Mediated by Cell Uropods}

A panel of blocking mAbs was used to dissect the adhesion molecules involved in the lymphocyte recruitment mediated through uropods. We found that mAb against ICAM- 1 and -3 , two molecules concentrated in the uropod, efficiently inhibited lymphocyte recruitment (Fig. $7 A$ ). In addition, the blockade of LFA-1, the counterreceptor for ICAM-1 and -3 (Campanero et al., 1993), also prevented these cellcell interactions. Moreover, the YTH81.5 antibody that reacts with the I domain of the LFA- $1 \alpha$ chain subunit and that selectively blocks the interaction with ICAM-3 but not with ICAM-1 (Landis et al., 1994) only produced a partial inhibition in cell recruitment. Interestingly, antibodies to CD43 and CD44, which are also concentrated in the uropod, as well as to CD45 that it is not redistributed (del Pozo et al., 1995) did not affect lymphocyte recruitment. Although T lymphoblasts express L-selectin (90\% positive cells; mean fluorescence intensity, 188 , versus negative control 5\%; mean fluorescence intensity, 15), a blocking $\mathrm{mAb}$ directed to L-selectin did not exert any effect on cell recruitment as measured in the time-lapse videomicroscopy assay (Fig. $7 A$ ). On the other hand, cell recruitment elicited by the HP2/19 anti-ICAM-3 mAb was abolished by coincubation with either of two different blocking anti-ICAM-3 mAbs but not with an anti-CD45 mAb (Fig. $7 \mathrm{~B})$. Together, these data demonstrate that the interaction of LFA-1 integrin with its ligands ICAM-1 and -3, located in the uropod, is critical for the process of lymphocyte recruitment mediated through chemokine-induced uropods.

\section{Enhanced Lymphocyte Transendothelial Migration under Conditions of Uropod Induction}

To explore whether the enhancement in lymphocyte interactions mediated by uropods could result in an increase of the transendothelial migration of the recruited cells, we carried out migration assays using a modified Boyden chamber (Transwell ${ }^{\circledR}$; Costar Corp.) and confluent monolayers of dermal microvascular endothelial cells (HMEC-1). We found that the induction of uropod formation in the first layer of T cells, adhered to EC, resulted in a significant enhancement of transmigration of ${ }^{51} \mathrm{Cr}$-labeled $\mathrm{T}$ cells of the second cohort (Fig. $8 A$ ); this effect was maximal at very short time periods (45-60 $\mathrm{min}$ ) and was detectable as early as after $15 \mathrm{~min}$ (Fig. $8 \mathrm{~B}$ ). Since lymphocyte migration was similar at 4-6 h, irrespective of the addition of uropod-inducing $\mathrm{mAb}$, it seems that the presence of uropods accelerates transendothelial migration rather than causes an enhancement of its overall magnitude. As expected, the enhancement of transmigration was dependent on the number of cells in the first layer of lymphocytes. Thus, $1.8 \times 10^{4}$ cells/ $\mathrm{mm}^{2}$ in the first layer under conditions of uropod induction, produced about a threefold enhancement in migration, compared to $4.5 \times 10^{3}$ lymphocytes $/ \mathrm{mm}^{2}$ (Fig. $8 \mathrm{C}$ ).

When the role of uropod in lymphocyte migration was studied by the migration assay described by Ager and Mistry (1988), using HEC, similar results were found. In this assay, $\mathrm{T}$ cells were coincubated with HEC, and after different periods of time, the number of lymphocytes bound to the apical surface or underneath the HEC monolayer were counted. We have also found that the induction of the uropod caused an important increment in the migration index in short periods of time, and that this effect vanished at longer times (Fig. 9 b). Interestingly, we observed that in these assays the interaction between migrated lymphocytes and bound $\mathrm{T}$ cells was also mediated through ICAM-3-bearing uropod structures (Fig. 9, $a$ and $c$ ), indicating that this interaction takes place during transendothelial migration.

The role of uropod in lymphocyte migration was confirmed with blocking experiments. We found that the increase in the migration was virtually abrogated by inhibition of uropod function in the first layer of T cells by using blocking anti-ICAM-3 mAb (Fig. $10 A$ ). In addition, the prevention of uropod formation with the myosin-disrupting drug butanedione monoxime also blocked the increment in transendothelial migration of the second cohort of T cells (Fig. $10 \mathrm{~B}$ ). This drug has previously been reported to prevent lymphocyte polarization and redistribution of adhesion molecules to the uropod (Campanero et al., 1994; del Pozo et al., 1995).

When we analyzed the expression of the adhesion molecules that redistribute to uropods before and after migration across HMEC-1, we found that they did not show any quantitative variation in their level of expression after lymphocyte transmigration; moreover, migrated cells exhibited a higher polarized morphology (Table I).

\section{Discussion}

Cell polarization is a complex phenomenon that results in asymmetrical cell shape common to many cell types and has a key role in cellular processes as diverse as activation, differentiation, localized membrane growth, cell migration, vectorial transport of molecules across cell layers, antigen presentation, and target cell recognition and killing (Rodriguez-Boulan and Powell, 1992; Huttenlocher et al., 1995; Drubin and Nelson, 1996; Helander et al., 1996; Lauffenburger et al., 1996; Negulescu et al., 1996). Lymphocytes are among the diverse cellular types that undergo polarization; activated and migrating lymphocytes change from a spherical to a polarized cell shape, displaying a cytoplasmic projection termed uropod due to its similarity with amoeboid morphology (Haston et al., 1982; Wilkinson, 1986; Wilkinson and Higgins, 1987; Shutt et al., 1995). We have previously described that chemotactic and 
A

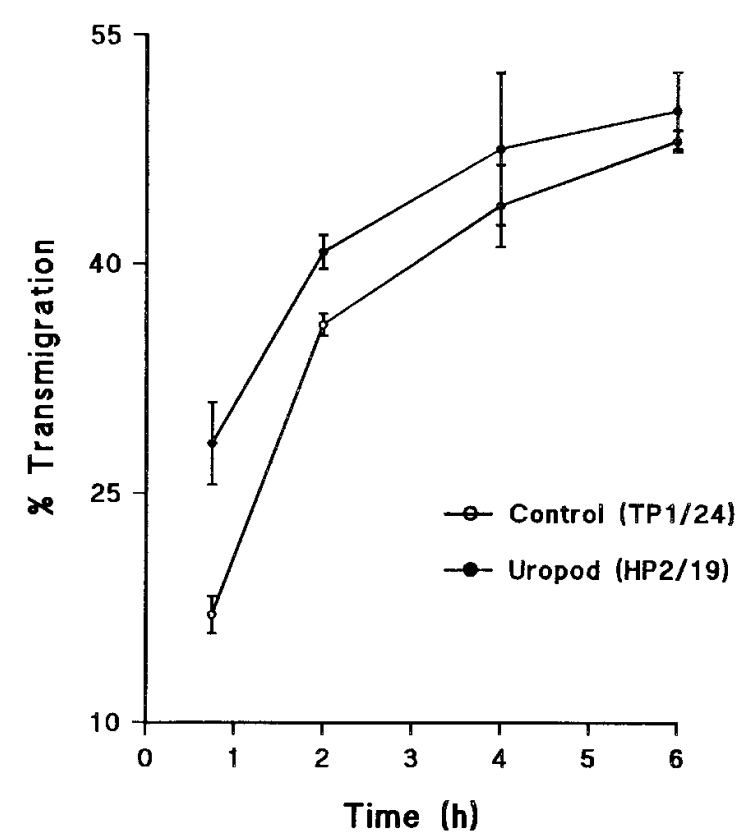

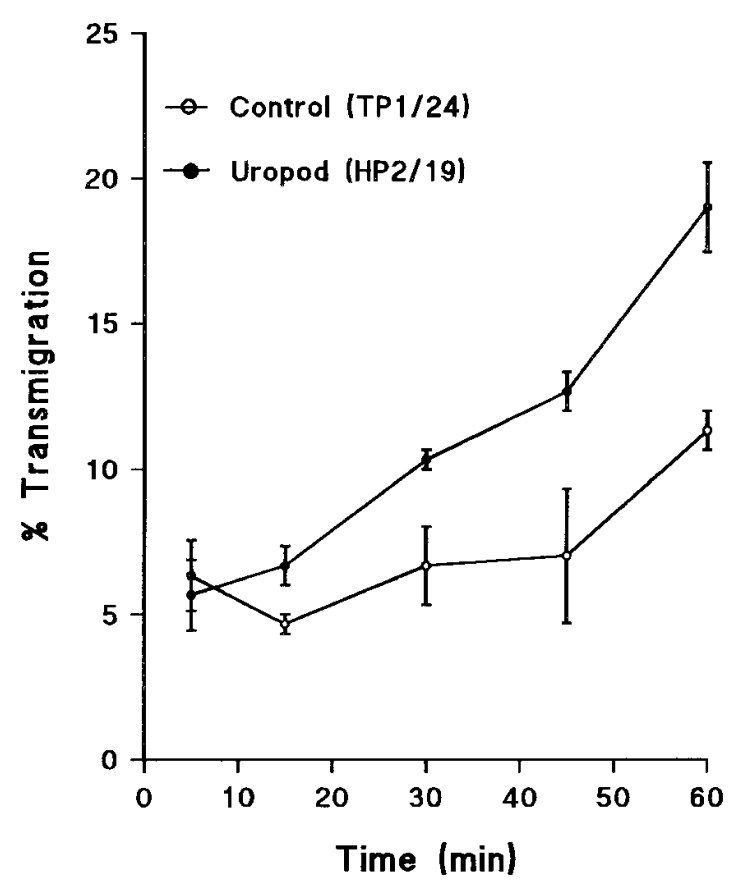

c

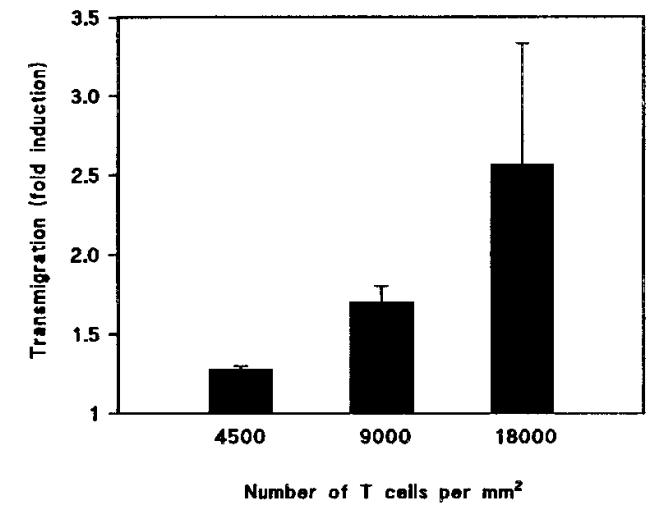

Figure 8. Effect of uropod induction on transendothelial migration of T lymphocytes. ( $A$ and $B)$ Uropod induction increases transendothelial migration. Migration of T lymphoblasts across confluent monolayers from a human dermal microvascular endothelial cell line (HMEC-1) was assayed in a Transwell cell culture chamber. T lymphoblasts were allowed to bind to confluent EC monolayers cultured on polycarbonate membranes and treated either with the uropod-inducing $\mathrm{mAb} \mathrm{HP} 2 / 19$ or with the noninducing anti-ICAM-3 mAb TP1/24. A second cohort of $10^{6}{ }^{51} \mathrm{Cr}$-labeled T cells was then added to the upper compartment of the chamber and incubated for long ( $A$, from $45 \mathrm{~min}$ to $6 \mathrm{~h}$ ) and short ( $B$, from 5 to $60 \mathrm{~min})$ periods of time at $37^{\circ} \mathrm{C}$ in a $5 \% \mathrm{CO}_{2}$ atmosphere. The percentage of cells that migrated to the lower well of the chamber was calculated using a $\gamma$ counter. A representative experiment out of five independent ones run in quadruplicate is shown. Error bars represent $\pm 1 \mathrm{SD}$ of values from quadruplicate Transwell chambers. $(C)$ The increment in migration was dependent on the number of cells in the first layer of lymphocytes. In similar experiments of transendothelial migration, different numbers of T lymphoblasts were incubated with the confluent EC monolayers, and migration of a second cohort of ${ }^{51} \mathrm{Cr}$-labeled T cells was analyzed. Transmigration is presented as the ratio between percentage of migrated cells under uropod conditions and percentage of migrated cells under nonuropod conditions. Arithmethic mean \pm 1 SD of three independent experiments is shown.

proinflammatory chemokines are responsible for the induction of the uropod on $\mathrm{T}$ cells adhered to endothelial cells, as well as for the redistribution of certain adhesion molecules to this structure (del Pozo et al., 1995). In this regard, it has been reported that these cytokines induce leukocyte chemotaxis and regulate adhesive properties of leukocyte integrins (Tanaka et al., 1993a,b; Taub et al., 1993a,b; Gilat et al., 1994; Schall and Bacon, 1994; Carr et al., 1996); however, the mechanisms responsible for these effects are poorly understood. We have found herein that chemokine-mediated cell polarization and adhesion molecule redistribution to the cellular uropod confers $\mathrm{T}$ lymphocytes the ability to capture additional cells through this structure. This phenomenon may constitute a cooperative mechanism that can significantly contribute to the directional guidance of leukocytes to inflammatory foci induced by chemokines.
We previously reported that uropods induced by both chemokines and activating mAb appear to emerge away from the flattened cell body that is adhered to EC or ECM substrate (Campanero et al., 1994; del Pozo et al., 1995; Sánchez-Mateos et al., 1995;). This point was inferred from conventional fluorescence microscopy studies in which we moved the plane of focus through the specimen. Very interestingly, we have confirmed our early observations by using confocal laser scanning fluorescence microscopy. This analysis allowed us to definitively conclude that the uropod is directed to the outer milieu, being projected from the flattened cell body, and furthermore, that this structure is able to mediate contacts among lymphocytes.

However, since confocal microscopy analysis only provided us a static approach to the understanding of the functional role of the uropod, several key questions remained undetermined. Therefore, we decided to under- 
a
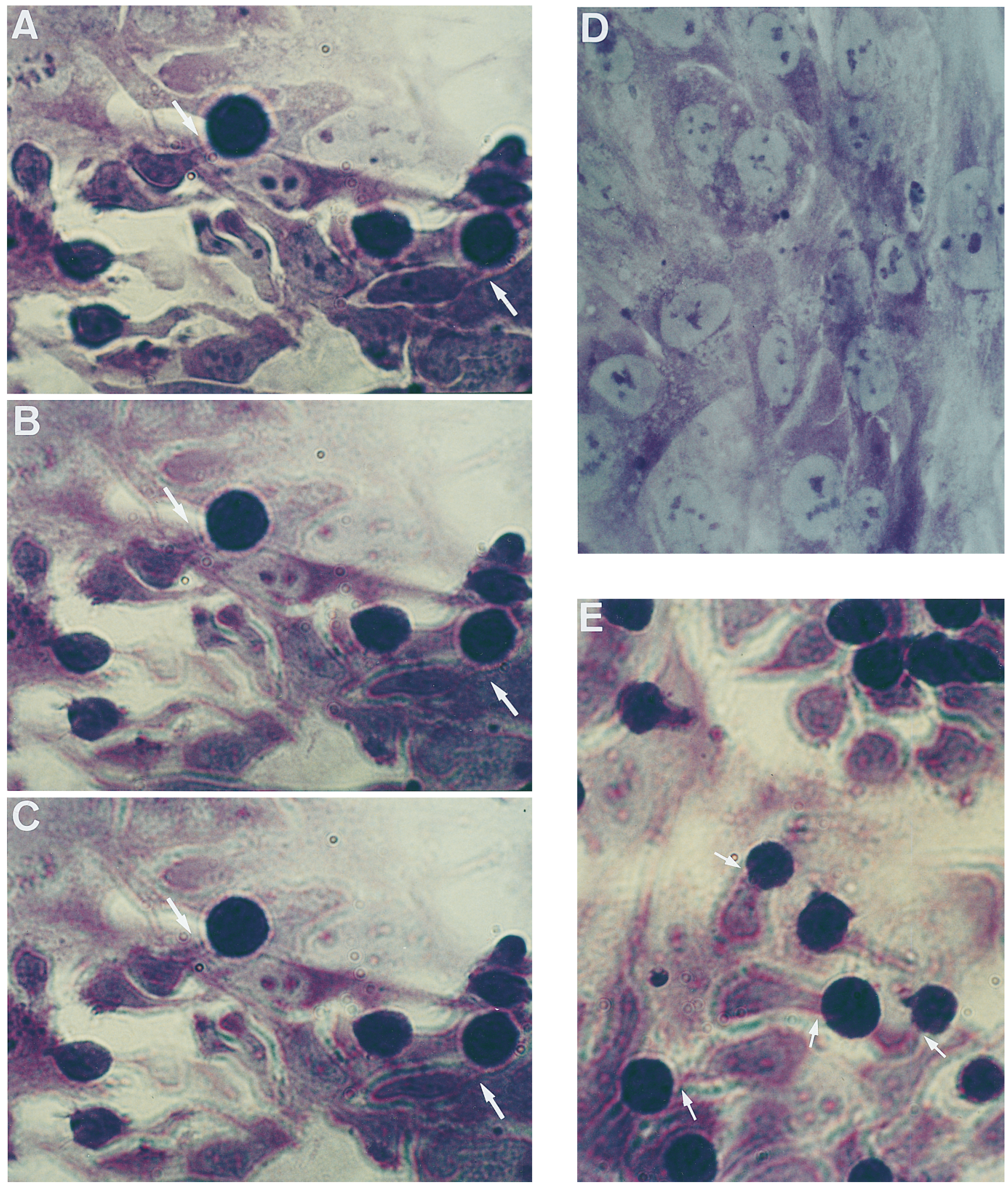

take a dynamic assessment of this issue by using a time lapse videocassette recorder coupled to a phase contrast microscope. Interestingly, this analysis showed that attached lymphocytes are able to move over the substrate displaying the uropod at the back of the cell, emerging from the most distal (antipodean) pole to the leading edge of the cell. Hence, this cellular projection corresponds exactly to the clasically defined lymphocyte uropod (Lewis, 1931; Haston et al., 1982). It is worth mentioning that we clearly observed that the cells captured through uropods were tightly engaged through these cellular structures and therefore migrated together with the uropod-bearing cell. 


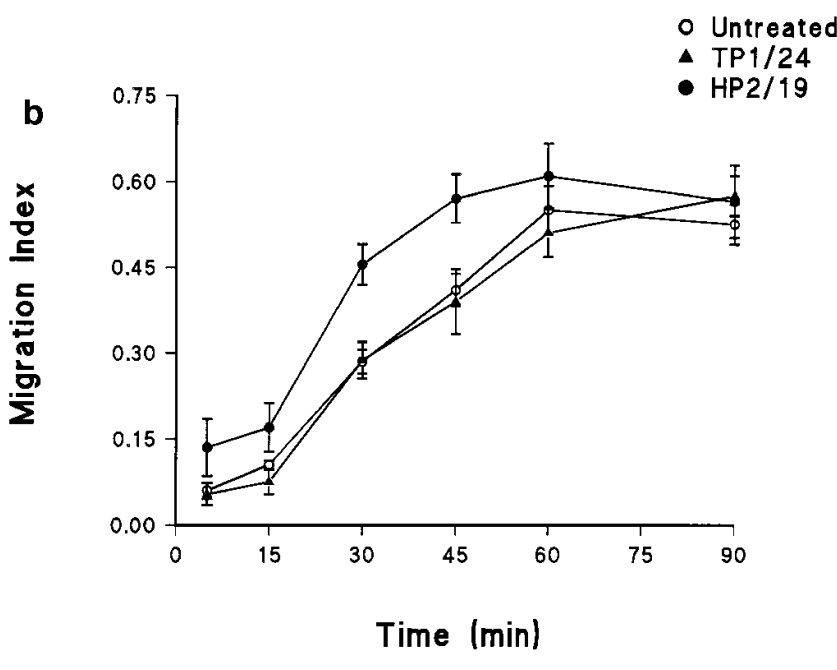

C
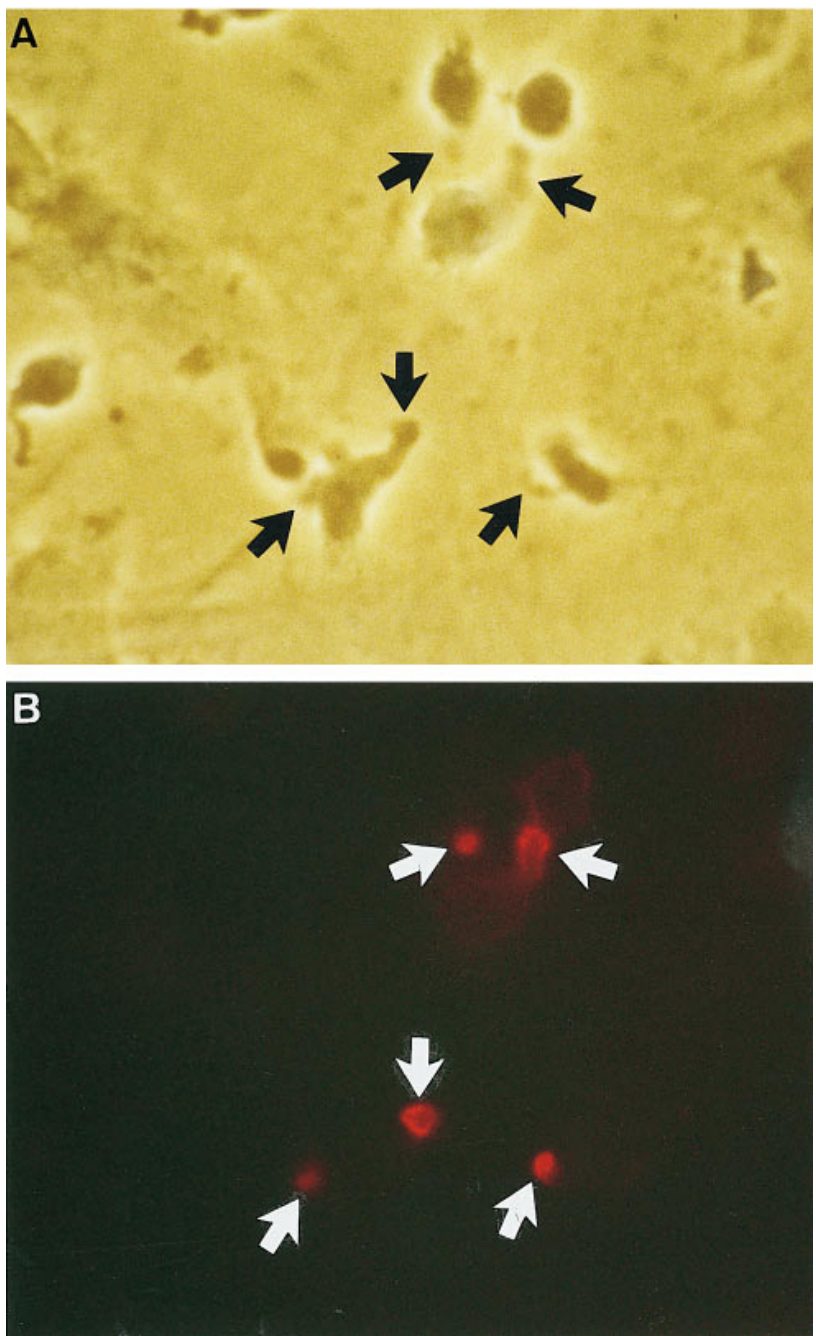

Figure 9. Uropod induction increases migration across HEC. (a) Interaction through a uropod-like structure between migrated T cells and bound lymphocytes. $D$ shows the usual morphology of high endothelial vein cells. $A-C$ show the same field photographed in a different plane of focus, from the level of HEC $(A)$ to the level of surface bound lymphocytes $(C)$. E shows a different field. White arrows point to cell-cell contacts through a uropodlike structure. (b) T lymphoblasts preincubated with the indicated
A

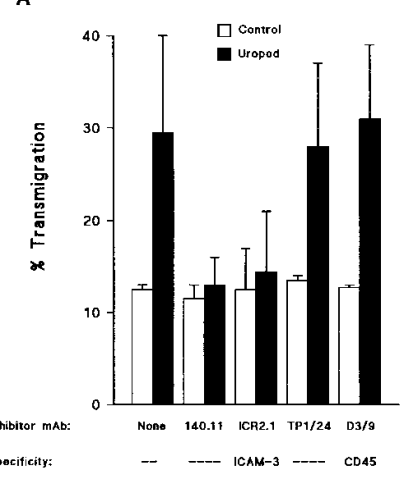

Figure 10. T cell migration mediated by cell uropods is prevented by blocking with anti-ICAM-3 mAbs or with drugs that impair uropod formation. T cell migration across HMEC-1 was assayed as described in Materials and Methods. $(A)$ After treatment of the first layer of T lymphoblasts with either HP2/19 (uropod) or TP1/ 24 (control) anti-ICAM-3 mAbs, cells were incubated for additional 15 min with the indicated blocking mAbs. $(B)$ Before the incubation of the first layer of T cells with the EC monolayers, lymphocytes were treated either with butanedione monoxime or with colchicine for $30 \mathrm{~min}$ at $37^{\circ} \mathrm{C}$, and then the drugs were extensively washed. In parallel, drug-treated lymphocytes were allowed to adhere to coverslips coated with $10 \mu \mathrm{g} / \mathrm{ml}$ ICAM-1-Fc for $30 \mathrm{~min}$ at $37^{\circ} \mathrm{C}$, fixed and stained for ICAM-3, and the proportion of uropod-bearing cells was calculated as described in Materials and Methods: untreated control, 11\%, uropod, $76 \%$; butanedione monoxime control, $1 \%$, uropod $4 \%$; colchicine control, $40 \%$, uropod, $81 \%$. A representative experiment out of three independent ones run in duplicate is shown.

Very importantly, we have found that this lymphocyte recruitment seems to be indeed relevant in vivo since it was also observed when uropods were promoted by physiologic stimuli such as chemokines. This phenomenon was strictly dependent on the presence of the uropod, since it did not occur upon cell stimulation with other agents that induce cell and integrin activation like phorbol esters, but was unable to induce uropod formation. These data strongly suggest that lymphocyte-lymphocyte interactions are cooperative for cell recruitment to sites where EC have been activated, bearing chemokines on their cell surface. On the other hand, and although there is no precedent for capture and transport of one leukocyte by another during transendothelial migration, there are several recent papers reporting on the synergism between leukocyte-leukocyte interactions as a novel regulatory mechanism in recruitment of leukocytes in inflammation (Bargatze et al., 1994; Alon et al.,

$\mathrm{mAb}$ were added to confluent cultures of HEC in multichamber polystyrene slides and incubated for different periods of time. After washing, adherent lymphocytes were identified as either "surface bound" or "transmigrated" by counterstaining with toluidine blue and high power light microscopy; the migration index was calculated as stated in Materials and Methods. A representative experiment out of three independent ones run in triplicate is shown. (c) In parallel, some specimens were stained for ICAM-3 after fixation as described in Materials and Methods. Same fields were photographed under bright field $(A)$ and epifluorescent $(B)$ conditions. Arrows point to ICAM $-3^{+}$uropods. 
Table I. Cell Polarization and Flow Cytometric Analysis of T cells during Migration across HMEC-1

\begin{tabular}{|c|c|c|c|c|c|c|c|c|}
\hline & \multicolumn{2}{|c|}{ Percentage of Polarized cells* } & \multicolumn{6}{|c|}{ Antigen expression ${ }^{\ddagger}$} \\
\hline & Unstimulated & RANTES & P3X63 & ICAM-1 & ICAM-3 & $\mathrm{CD} 43$ & CD44 & CD45 \\
\hline Before migration & 1 & 17 & $4 \pm 2$ & $15 \pm 8$ & $134 \pm 41$ & $157 \pm 54$ & $428 \pm 145$ & $497 \pm 108$ \\
\hline After migration & 24 & 71 & $4 \pm 1$ & $16 \pm 6$ & $141 \pm 40$ & $174 \pm 58$ & $421 \pm 139$ & $487 \pm 102$ \\
\hline
\end{tabular}

Data shown are from a representative experiment out of three independent ones.

*T lymphoblasts were collected before and $5 \mathrm{~h}$ after migration across HMEC-1 and allowed to bind to ICAM-1-coated coverslips for 30 min at $37^{\circ} \mathrm{C}$ in the presence or in the absence of chemokine RANTES (10 ng/ml). Fixed cells were then stained for ICAM-3, and the percentage of polarized cells (with ICAM-3 redistributed to the uropod) was calculated as previously described (del Pozo et al., 1995).

${ }^{\ddagger} \mathrm{mAbs}$ were used to detect surface expression of ICAM-1, -3, CD43, CD44, and CD45 on T lymphoblasts before and $5 \mathrm{~h}$ after migration across HMEC-1. The fluorescence was measured on a FACS ${ }^{\circledR}$ can (Becton Dickinson), and results are expressed as a mean fluorescence intensity \pm 1 SD of 2,000 cells per determination. Staining with the negative control P3X63 $\mathrm{IgG}_{1}$ myeloma protein is also shown.

1996; Jutila and Kurk, 1996; Finger et al., 1996; Fuhlbrigge et al., 1996). L-selectin plays an important role in these cell-cell interactions as determined by blocking studies with specific antibodies. However, in our experiments the blockade of L-selectin did not interfere with lymphocyte recruitment, since we have looked at the tight adhesion between lymphocytes ( $\beta_{2}$ integrin/ICAM-1,-3-dependent) rather than at the rolling phase observed under flow conditions (selectin-dependent; Springer, 1995; Butcher and Picker, 1996). Therefore, our results do not rule out the possible involvement of L-selectin and its carbohydrate ligands in the process of lymphocyte recruitment under flow conditions. In this regard, it is worth mentioning that the ligand of P-selectin PSGL-1, which also binds L-selectin, has been detected on the uropods of activated, polarized neutrophils (Lorant el al., 1995).

Altogether our findings on cell recruitment suggested that $T$ cell interactions through the uropod can significantly increase migration through an endothelial barrier and underlying ECM to inflammatory foci. To further support this point we performed specific transendothelial migration assays. Under conditions of uropod formation, lymphocyte migration through dermal microvascular endothelial cells was clearly enhanced. It is worth mentioning that most of the previously reported assays of lymphocyte chemotaxis have been performed using inert polycarbonate filters. At best, endothelial cells derived from the umbilical cord vein (HUVEC) have been used by some authors (Roth et al., 1995; Randolph and Furie, 1996) in an attempt to model the blood vessel wall. The use of HUVEC increases the signal to background ratio of chemotaxis and provides a more physiologic model of lymphocyte emigration from the bloodstream than the conventional in vitro chemotaxis assays lacking endothelium (Roth et al., 1995). However, it is evident that lymphocyte extravasation occurs primarily through postcapillary venules rather than through large vessels such as the umbilical vein. To our knowledge, this is one of the first reports employing microvascular endothelium specialized in diapedesis in chemotaxis assays. Furthermore, we have also studied lymphocyte migration through high endothelial venules. The endothelial cells from high endothelial venules stem from specialized postcapillary vascular sites in lymphoid organs that are able to support high levels of lymphocyte extravasation (Ager and Mistry, 1988; Girard and Springer, 1995). Interestingly, we found that in both systems, uropods significantly enhance $\mathrm{T}$ cell transmigration at very short time periods. In this regard, TNF- $\alpha$ stimulation of HMEC-1 also rendered an initial increment in lymphocyte migration, whereas at longer periods of time the transmigration level was equal to nonstimulated EC (not shown). Therefore, different phenomena such as the generation of lymphocyte uropods or activation of HMEC-1 by TNF- $\alpha$ rendered a similar effect in transendothelial migration. It is worth mentioning the existence of contacts through ICAM-3-bearing uropods during cell transmigration. Unfortunately, we could not fully assess the effect of exogenously applied chemokines on uropod formation in our migration assays, since the presence of chemokines in the upper compartment of the chamber would impair lymphocyte transendothelial migration towards the lower compartment by an inversion of the chemotactic gradient generated by the dermal microvascular endothelial cells. However, our clearcut results on the effect of chemokines in T cell recruitment strongly suggest their involvement in transendothelial migration.

Lymphocytes that are recruited into inflamed tissues bear preferentially the memory/activated $\mathrm{CD} 45 \mathrm{R} 0^{+}$phenotype (Carr et al., 1994). It is now becoming clear that within the $\mathrm{T}$ lineage, most of the chemokine receptors are restricted to $\mathrm{CD}_{45 \mathrm{R}^{+}}$cells (Loetscher et al., 1996; Mackay, 1996). T cells that migrate in response to RANTES, MCP-1, and MIP-1 $\alpha$ are mainly CD45RA ${ }^{-}$CD45R $0^{+}$memory T cells (Qin et al., 1996). In this context we have found that these chemokines act preferentially on freshly isolated $\mathrm{CD} 45 \mathrm{R} 0^{+}$cells inducing uropod formation, and therefore, these cells are able to recruit other T cells through the uropod. Furthermore, physiologically in vivo activated $\mathrm{CD}_{45 \mathrm{R}^{+}} \mathrm{T}$ lymphocytes isolated from inflammatory infiltrates of rheumatoid arthritis patients and TIL displaying a highly polarized morphology were able to recruit $\mathrm{T}$ cells very efficiently. Altogether, these results provide evidence that the mechanism of uropod-mediated lymphocyte recruitment has in vivo physiologic relevance.

In additional experiments of cell recruitment, we have observed that this phenomenon is not only induced when lymphocytes are attached to adhesion molecules expressed by inflamed endothelium (VCAM-1 or ICAM-1) but also to extracellular matrix proteins such as fibronectin, as shown for TIL. In this regard, it is well known that the chemotactic gradients produced by chemokines occur underneath the endothelial barrier, and we have recently found that uropods are efficiently promoted by chemokines on lymphocytes adhered to several ECM substrates (del Pozo et al., 1995). Moreover, the adhesion molecules that redistribute to uropods do not show any quantitative variation in their level of expression after lymphocyte migration across 
HMEC-1, and migrated cells exhibit a higher polarized cell morphology. Therefore, it is conceivable that uropods could also play a role in leukocyte recruitment once cells have extravasated and are migrating towards the inflammatory foci. In this regard, this issue is underscored by the observations that TIL adhering to a monolayer of the original melanoma tumor cells are able to recruit other lymphocytes through the uropod. Lymphocyte recruitment mediated by uropods could therefore represent a general mechanism of major importance during a wide variety of immunological processes in which cell migration is involved.

The generous gift of mAbs is gratefully acknowledged to Drs. F.W. Luscinskas, R. Vilella, W.M. Gallatin, C.G. Figdor, T.F. Tedder, and P. Beverley. We thank Dr. N. Hogg for allowing the use of confocal and videomicroscopy facilities of Imperial Cancer Research Foundation (London, UK) and Liz Hirst (National Institute for Medical Research, London, UK) and Dr. Andrew Edwards (Imperial Cancer Research Foundation, London, UK) for technical assistance with confocal microscopy. We thank Dr. J. García-Sancho for excellent immunofluorescence technical advice, Dr. Natividad Longo and Dr. I. González-Alvaro for providing pathologic samples, and Dr. R. González-Amaro for critical reading of the manuscript.

This work was supported by a grant SAF96-0039 from Plan Nacional de Investigación y Desarrollo, 07/44/96 from Comunidad Autónomia de Madrid, and from Asociación de la Lucha contra el Cancer to F. SánchezMadrid and by fellowships from Fondo de Investigaciones Sanitarias BAE 96/5357 (to M.A. del Pozo) and Comunidad Autónoma de Madrid (to M.C. Montoya).

Received for publication 30 September 1996 and in revised form 30 December 1996.

\section{References}

Ades, E.W., F.J. Candal, R.A. Swerlick, V.G. George, S. Summers, D.C. Bosse, and T.J. Lawley. 1992. HMEC-1: establishment of an immortalized human microvascular endothelial cell line. J. Investig. Dermatol. 99:683-690.

Ager, A. 1987. Isolation and culture of high endothelial cells from rat lymph nodes. J. Cell Sci. 87:133-144.

Ager, A., and S. Mistry. 1988. Interactions between lymphocytes and cultured high endothelial cells: an in vitro model of lymphocyte migration across high endothelial venule endothelium. Eur. J. Immunol. 18:1265-1274.

Alon, R., R.C. Fuhlbrigge, E.B. Finger, and T.A. Springer. 1996. Interactions through L-selectin between leukocytes and adherent leukocytes nucleate rolling adhesions on selectins and VCAM-1 in shear flow. J. Cell Biol. 135: 849-865.

Arroyo, A.G., M.R. Campanero, P. Sánchez-Mateos, J.M. Zapata, M.A. Ursa, M.A. del Pozo, and F. Sánchez-Madrid. 1994. Induction of tyrosine phosporylation during ICAM-3 and LFA-1-mediated intercellular adhesion and its regulation by the CD45 tyrosine phosphatase. J. Cell Biol. 126:1277-1286.

Baggiolini, M., B. Dewald, and B. Moser. 1994. Interleukin-8 and related chemotactic cytokines: CXC and CC chemokines. Adv. Immunol. 55:97-179.

Bargatze, R.F., S. Kurk, E.C. Butcher, and M.A. Jutila. 1994. Neutrophils roll on adherent neutrophils bound to cytokine-induced endothelial cells via L-selectin on the rolling cells. J. Exp. Med. 180:1785-1792.

Butcher, E.C., and L.J. Picker. 1996. Lymphocyte homing and homeostasis. Science (Wash. DC). 272:60-66.

Campanero, M.R., M.A. del Pozo, A.G. Arroyo, P. Sánchez-Mateos, T. Hernández-Caselles, A. Craig, R. Pulido, and F. Sánchez-Madrid. 1993. ICAM-3 interacts with LFA-1 and regulates the LFA-1/ICAM-1 cell adhesion pahtway. J. Cell Biol. 123:1007-1016.

Campanero, M.R., P. Sánchez-Mateos, M.A. del Pozo, and F. Sánchez-Madrid. 1994. ICAM-3 regulates lymphocyte morphology and integrin-mediated $\mathrm{T}$ cell interaction with endothelial cell and extracellular matrix ligands. J. Cell Biol. 127:867-878.

Carr, M.W., S.J. Roth, E. Luther, S.S. Rose, and T.A. Springer. 1994. Monocyte chemoattractant protein 1 acts as a T lymphocyte chemoattractant. Proc. Natl. Acad. Sci. USA. 91:3652-3656.

Carr, M.W., R. Alon, and T.A. Springer. 1996. The C-C- chemokine MCP-1 differentially modulates the avidity of $\beta 1$ and $\beta 2$ integrins on $T$ lymphocytes. Immunity. 4:179-187.

del Pozo, M.A., P. Sánchez-Mateos, M. Nieto, and F. Sánchez-Madrid. 1995. Chemokines regulate cellular polarization and adhesion receptor redistribution during lymphocyte interaction with endothelium and extracellular matrix. Involvement of cAMP signaling pathway. J. Cell Biol. 131:495-508.

Dransfield, I., C. Cabañas, J. Barrett, and N. Hogg. 1992. Interaction of leuko- cyte integrins with ligands is necessary but not sufficient for function. J. Cell Biol. 116:1527-1535.

Drubin, D.G., and W.J. Nelson. 1996. Origins of cell polarity. Cell. 84:335-344.

Finger, E.B., K.D. Puri, R. Alon, M.B. Lawrence, U.H. von Adrian, and T.A. Springer. 1996. Adhesion through L-selectin requires a threshold hydrodynamic shear. Nature (Lond.). 379:266-269.

Fuhlbrigge, R.C., Alon, R., Puri, K.D., Lowe, J.B., and T.A. Springer. 1996. Sialylated, fucosylated ligands for L-selectin expressed on leukocytes mediate tethering and rolling adhesions in physiologic flow conditions. J. Cell Biol. 135:837-848.

Gilat, D., R. Hershoviz, Y.A. Mekori, I. Vlodavsky, and O. Lider. 1994. Regulation of adhesion of $\mathrm{CD}^{+} \mathrm{T}$ lymphocytes to intact or heparinase-treated subendothelial extracellular matrix by diffusible or anchored RANTES and MIP-1ß. J. Immunol. 153:4899-4905.

Girard, J.P., and T.A. Springer. 1995. High endothelial venules (HEVs): specialized endothelium for lymphocyte migration. Immunol. Today. 16:449-457.

Haston, W.S., J.M. Shields, and P.C. Wilkinson. 1982. Lymphocyte locomotion and attachment on two-dimensional surfaces and in three-dimensional matrices. J. Cell Biol. 92:747-752.

Helander, T.S., O. Carpén, O. Turunen, P.E. Kovanen, A. Vaheri, and T. Timonen. 1996. ICAM-2 redistributed by ezrin as a target for killer cells. $\mathrm{Na}$ ture (Lond.). 382:265-268.

Huttenlocher, A., R.R. Sandborg, and A.F. Horwitz. 1995. Adhesion in cell migration. Curr. Opin. Cell Biol. 7:697-706.

Itoh, K., C.D. Platsoucas, and C.M. Balch. 1988. Autologous tumor specific cytotoxic T lymphocytes in the infiltrate of human metastatic melanomas: activation by IL-2 and autologous tumor cells, and involvement of the T cell receptor. J. Exp. Med. 168:1419-1425.

Juan, M., O. Viñas, M.R. Pino-Otín, L. Places, E. Martínez-Cáceres, J.J. Barceló, A. Miralles, R. Vilella, M.A. de la Fuente, J. Vives, et al. 1994. CD50 (intercellular adhesion molecule 3) stimulation induces calcium mobilization and tyrosine phosphorylation through $\mathrm{p} 59^{\mathrm{fyn}}$ and $\mathrm{p} 56^{\mathrm{lck}}$ in Jurkat $\mathrm{T}$ cell line. J. Exp. Med. 179:1747-1756.

Jutila, M.A., and S. Kurk. 1996. Analysis of bovine $\gamma \delta$ T cell interactions with E-, P-, and L-selectin: characterization of lymphocyte on lymphocyte rolling and the effects of $O$-glycoprotease. J. Immunol. 156:289-296.

Landis, R.C., A. McDowall, C.L.L. Holness, A.J. Littler, D.L. Simmons, and N. Hogg. 1994. Involvement of the "I" domain of LFA-1 in selective binding to ligands ICAM-1 and ICAM-3. J. Cell Biol. 126:529-537.

Lauffenburger, D.A., and A.F. Horwitz. 1996. Cell migration: a physically integrated molecular process. Cell. 84:359-369.

Lewis, W.H. 1931. Locomotion of lymphocytes. Bull. Johns Hopkins Hosp. 49: $29-36$.

Loetscher, P., M. Seitz, M. Baggiolini, and B. Moser. 1996. Interleukin-2 regulates $\mathrm{CC}$ chemokine receptor expression and chemotactic responsiveness in T lymphocytes. J. Exp. Med. 184:569-577.

Lorant, D.E., R.P. McEver, T.M. McIntyre, K.L. Moore, S.M. Prescott, and G.A. Zimmerman. 1995. Activation of polymorphonuclear leukocytes reduces their adhesion to P-selectin and causes redistribution of ligands for P-selectin on their surfaces. J. Clin. Invest. 96:171-182.

Luscinskas, F.W., G.S. Kansas, H. Ding, P. Pizcueta, B.E. Schleiffenbaum, T.F. Tedder, and M.A. Gimbrone, Jr. 1994. Monocyte rolling, arrest, and spreading on IL-4-activated vascular endothelium under flow is mediated via sequential action of L-selectin, $\beta_{1}$-integrins, and $\beta_{2}$-integrins. J. Cell Biol. 125: $1417-1427$.

Mackay, C.R. 1996. Chemokine receptors and T cell chemotaxis. J. Exp. Med. 184:799-802.

Negulescu, P.A., T.B. Krasieva, A. Khan, H.H. Kerschbaum, and M.D. Cahalan. 1996. Polarity of T cell shape, motility, and sensitivity to antigen. Immunity. 4:421-430.

Nieto, M., M.A. del Pozo, and F. Sánchez-Madrid. 1996. Interleukin-15 induces adhesion receptor redistribution in T lymphocytes. Eur. J. Immunol. 26: 1302-1307.

Qin, S., G. LaRosa, J.J. Campbell, H. Smith-Heath, N. Kassam, X. Shi, L. Zeng, E.C. Butcher, and C.R. Mackay. 1996. Expression of monocyte chemoattractant protein-1 and interleukin-8 receptors on subsets of T cells: correlation with transendothelial chemotactic potential. Eur. J. Immunol. 26:640-647.

Randolph, G.J., and M.B. Furie. 1996. Mononuclear phagocytes egress from an in vitro model of the vascular wall by migrating across endothelium in the basal to apical direction: role of intercellular adhesion molecule 1 and the CD11/CD18 integrins. J. Exp. Med. 183:451-462.

Rodriguez-Boulan, E., and S.K. Powell. 1992. Polarity of epithelial and neuronal cells. Annu. Rev. Cell Biol. 8:395-427.

Roth, S.J., M.W. Carr, S.S. Rose, and T.A. Springer. 1995. Characterization of transendothelial chemotaxis of T lymphocytes. J. Immunol. Methods. 188: $97-116$.

Rotrosen, D., and J.I. Gallin. 1986. Histamine type I receptor occupancy increases endothelial cytosolic calcium, reduces F-actin, and promotes albumin diffusion across cultured endothelial monolayers. J. Cell Biol. 103:23792387.

Sadhu, C., B. Lipsky, H.P. Erickson, J. Hayflick, K.O. Dick, M.W. Gallatin, and D.E. Staunton. 1994. LFA-1 binding site in ICAM-3 contains a conserved motif and noncontiguous amino acids. Cell Adhes. Commun. 2:429-440.

Sánchez-Mateos, P., M.R. Campanero, M.A. del Pozo, and F. Sánchez-Madrid. 1995. Regulatory role of CD43 leukosialin on integrin-mediated T cell adhe- 
sion to endothelial and extracellular matrix ligands and its polar redistribution to a cellular uropod. Blood. 86:2228-2239.

Schall, T.J., and K.B. Bacon. 1994. Chemokines, leukocyte trafficking, and inflammation. Curr. Opin. Immunol. 6:865-873.

Schall, T.J., K. Bacon, K.J. Toy, and D.V. Goeddel. 1990. Selective attraction of monocytes and $\mathrm{T}$ lymphocytes of the memory phenotype by cytokine RANTES. Nature (Lond.). 347:669-671.

Schall, T.J., K. Bacon, R.D.R. Camp, J.W. Kaspari, and D.V. Goeddel. 1993. Human macrophage inflammatory protein $\alpha$ (MIP- $1 \alpha)$ and MIP-1 $1 \beta$ chemokines attract distinct populations of lymphocytes. J. Exp. Med. 177:1821-1825.

Shutt, D.C., D. Wessels, K. Wagenknecht, A. Chandrasekhar, A.L. Hitt, E.J. Luna, and D.R. Soll. 1995. Ponticulin plays a role in the positional stabilization of pseudopods. J. Cell Biol. 131:1495-1506.

Spertini, O., G.S. Kansas, K.A. Reimann, C.R. Mackay, and T.F. Tedder. 1991. Function and evolutionary conservation of distinct epitopes on the leukocyte adhesion molecule-1 (TQ-1, Leu-8) that regulate leukocyte migration. J. Immunol. 147:942-949.

Springer, T.A. 1995. Traffic signals on endothelium for lymphocyte recirculation and leukocyte emigration. Annu. Rev. Physiol. 57:827-872.

Tanaka, Y., D.H. Adams, S. Hubscher, H. Hirano, U. Siebenlist, and S. Shaw. 1993a. T-cell adhesion induced by proteoglycan-immobilized cytokine MIP1ß. Nature (Lond.). 361:79-82.

Tanaka, Y., D.H. Adams, and S. Shaw. 1993b. Proteoglycans on endothelial cells present adhesion-inducing cytokines to leukocytes. Immunol. Today. $14: 111-115$

Taub, D.D., K. Conlon, A.R. Lloyd, J.J. Oppenheim, and D.J. Kelvin. $1993 a$. Preferential migration of activated $\mathrm{CD} 4^{+}$and $\mathrm{CD}^{+} \mathrm{T}$ cells in response to
MIP- $1 \alpha$ and MIP-1 $\beta$. Science (Wash. DC). 260:355-358.

Taub, D.D., A.R. Lloyd, K. Conlon, J.M. Wang, J.R. Ortaldo, A. Harada, K. Matsushima, D.J. Kelvin, and J.J. Oppenheim. 1993b. Recombinant human interferon-inducible protein 10 is a chemoattractant for human monocytes and T lymphocytes and promotes T cell adhesion to endothelial cells. J. Exp. Med. 177:1809-1814.

Taub, D.D., P. Proost, W. Murphy, D. Longo, J. van Damme, and J.J. Oppenheim. 1995. Monocyte chemotactic protein (MCP-1) -2, -3 are chemoattractant for human T lymphocytes. J. Clin. Invest. 95:1370-1376.

van Kooyk, Y., P. Weder, F. Hogervorst, A.J. Verhoeven, G. van Seventer, A.A. te Velde, J. Borst, G.D. Keizer, and C.G. Figdor. 1991. Activation of LFA-1 through a $\mathrm{Ca}^{2+}$-dependent epitope stimulates lymphocyte adhesion. J. Cell Biol. 112:345-354.

Vartdal, F., G. Kvalheim, T.E. Lea, V. Bosnes, G. Gaudernack, J. Ugelstad, and D. Albrechtsen. 1987. Depletion of T lymphocytes from human bone marrow. Use of magnetic monosized polymer microspheres coated with $\mathrm{T}$ lymphocyte specific monoclonal antibodies. Transplantation (Baltimore). 43: 366-371.

Weber, C., R. Alon, B. Moser, and T.A. Springer. 1996. Sequential regulation of $\alpha 4 \beta 1$ and $\alpha 5 \beta 1$ integrin avidity by CC chemokines in monocytes: implications for transendothelial chemotaxis. J. Cell Biol. 134:1063-1073.

Wilkinson, P.C. 1986. The locomotor capacity of human lymphocytes and its enhancement by cell growth. Immunology. 57:281-289.

Wilkinson, P.C., and A. Higgins. 1987. OKT3-activated locomotion of human blood lymphocytes: a phenomenon requiring contact of $\mathrm{T}$ cells with $\mathrm{Fc}$ receptor-bearing cells. Immunology. 60:445-451. 